Cornell Law Library

Scholarship@Cornell Law: A Digital Repository

Cornell Law Faculty Publications

Faculty Scholarship

$4-1998$

\title{
Questioning the "New Consensus" on Promissory Estoppel: An Empirical and Theoretical Study
}

Robert A. Hillman

Cornell_Law School, rah16@cornell.edu

Follow this and additional works at: http://scholarship.law.cornell.edu/facpub

Part of the Contracts Commons

\section{Recommended Citation}

Hillman, Robert A., "Questioning the "New Consensus" on Promissory Estoppel: An Empirical and Theoretical Study" (1998). Cornell Law Faculty Publications. Paper 1069.

http://scholarship.law.cornell.edu/facpub/1069

This Article is brought to you for free and open access by the Faculty Scholarship at Scholarship@Cornell Law: A Digital Repository. It has been accepted for inclusion in Cornell Law Faculty Publications by an authorized administrator of Scholarship@Cornell Law: A Digital Repository. For more information, please contact jmp8@cornell.edu. 


\title{
QUESTIONING THE "NEW CONSENSUS" ON PROMISSORY ESTOPPEL: AN EMPIRICAL AND THEORETICAL STUDY
}

\author{
Robert A. Hillman*
}

Professor Hillman presents evidence that contradicts several assumptions about how courts apply the doctrine of promissory estoppel. Although theorists have claimed the importance, even dominance, of the theory as a ground for enforcing promises, he shows that the theory is remarkably unsuccessful in the courts. Professor Hillman also demonstrates the crucial role of reliance in both successful and unsuccessful promissory estoppel cases, despite the "new consensus" that courts enforce promises without a showing of reliance. Finally, Professor Hillman shows that courts award damages flexibly in successful promissory estoppel cases, although analysts have claimed that courts strongly favor expectancy damages.

Professor Hillman derives his evidence from a data pool of all of the reported decisions in the United States for a two-year period in the mid-1990s in which a promissony estoppel claim either succeeded or failed or in which a court discussed promissory estoppel. He reports the results of a systematic survey of these cases. He also analyzes and discusses a representative sample of the cases in greater depth. In addition, Professor Hillman reexamines some of the cases in earlier studies that led others to report incorrectly the unimportance of reliance.

Professor Hillman also discusses why promissory estoppel has been so unsuccessful in the courts. He surmises that claimants may have overestimated the chances of success because of their failure to comprehend a judicial souring on the theory. Another possible explanation is that claimants often bring weak secondary claims of promissory estoppel. Professor Hillman leaves for another day the question of whether promissory estoppel should be more successful and whether promissory estoppel should require reliance.

\section{INTRODUCTION}

The purpose of this Article is to present evidence of a fundamental misunderstanding of how courts apply the theory of obligation called promissory estoppel. Contrary to the accepted wisdom, the data and analysis presented here (1) demonstrate that the theory seldom leads to victory in reported decisions, (2) underscore the immense importance of

* Edwin Woodruff Professor of Law, Cornell Law School. Thanks to my colleague, Ted Eisenberg, for his great patience in teaching me how to enter and analyze the data. Jean Braucher, Kevin Clermont, Ted Eisenberg, Allan Farnsworth, Jim Henderson, Stewart Macaulay, and Jeff Rachlinski read the manuscript and provided helpful insights. Thanks also to Karen Wilson, my secretary, for entering the data. Hera Arsen, David Becker, Gillian Crenshaw, George Caballero, Kevin Deborde, Anita Lee, and David Passey, students at the Cornell Law School, compiled the data and I thank them too. David Becker deserves special thanks for understanding and operating the Stata 5.0 data analysis program. 
reliance as a substantive element of the theory, and (3) suggest the willingness of courts to grant reliance damages to successful litigants.

The first point, the lack of success of the theory in the courts, contradicts theorists who predicted that promissory estoppel would "swallow up" the bargain theory of contract and become the dominant promissory theory of obligation. ${ }^{1}$ Although some writers have questioned the prediction, ${ }^{2}$ this Article is the first comprehensive empirical study that demonstrates promissory estoppel's limited role. ${ }^{3}$

Until the mid-1980s, the second and third points would not have been controversial. Anyone familiar with promissory estoppel believed that, along with a promise, one of the critical elements of promissory estoppel was detrimental reliance on the promise. ${ }^{4}$ After all, the theory developed because of the injustice of the law's failure to enforce certain promises that induced detrimental reliance, and section 90 of both the first and second Restatement of Contracts set forth reliance as a principal element of the theory. ${ }^{5}$ Because a remedy should be consistent with the substantive theory it reinforces, analysts also believed that the appropriate and most utilized remedy was reliance damages. ${ }^{6}$ In 1985, however, Professors Farber and Matheson published their study of promissory estoppel cases that questioned the accepted wisdom. ${ }^{7}$ They reported that courts had significantly expanded the theory to enforce any promise made "in furtherance of an economic activity." A few years later, Professors Yorio and Thel announced that courts enforce "serious"

1. See, e.g., Grant Gilmore, The Death of Contract 72 (1974); see also infra notes 33-36 and accompanying text.

2. See Robert A. Hillman, The Richness of Contract Law 28-32 (1997); E. Allan Farnsworth, Developments in Contract Law During the 1980's: The Top Ten, 41 Case W. Res. L. Rev. 203, 219-20 (1990); Phuong N. Pham, Note, The Waning of Promissory Estoppel, 79 Cornell L. Rev. 1263, 1263 (1994).

3. Cf. Pham, supra note 2, at 1271-73 (study of New York and California cases). Professor Sidney W. DeLong's impressive study of promissory estoppel cases was published too late to be discussed in this Article. See Sidney W. DeLong, The New Requirement of Enforcement Reliance in Commercial Promissory Estoppel: Section 90 as Catch 22, 1997 Wis. L. Rev. 943 (1997).

4. See, e.g., John D. Calamari \& Joseph M. Perillo, The Law of Contracts 273 (3d ed. 1987); Warren A. Seavey, Reliance Upon Gratuitous Promises or Other Conduct, 64 Harv. L. Rev. 913, 926 (1951).

5. See Restatement of Contracts $\S 90$ (1932) ("A promise which the promisor should reasonably expect to induce action or forbearance ... which does induce such action or forbearance is binding ... ."); Restatement (Second) of Contracts $\$ 90$ (1981) (same); Melvin Aron Eisenberg, The World of Contract and the World of Gift, 85 Cal. L. Rev. 821, 859 (1997). But see Edward Yorio \& Steve Thel, The Promissory Basis of Section 90, 101 Yale L.J. 111, 129 (1991) ("The changes in the Second Restatement reflect a reliance-based view of Section 90 that differs considerably from the promissory conception of the First Restatement.").

6. See Hillman, supra note 2, at 54-60 (discussing analysts' view of remedies).

7. See Daniel A. Farber \& John H. Matheson, Beyond Promissory Estoppel: Contract Law and the "Invisible Handshake," 52 U. Chi. L. Rev. 903 (1985).

8. Id. at 904-05. 
promises regardless of whether the promisee relied on them. ${ }^{9}$ Both articles also recounted courts' widespread use of expectancy damages in supplying a remedy for successful plaintiffs. ${ }^{10}$

These articles, which I shall call the "promise studies," have been enormously influential, at least in the secondary literature on promissory estoppel. Other analysts writing about promissory estoppel, and more generally about the law of promise enforcement, treat the works as forming a "new consensus" and assume the accuracy of the articles in building their own theses. For example, James Gordley wrote: "Farber and Matheson suggested, and Yorio and Thel have recently confirmed, that most often the promisee recovers under the doctrine [of promissory estoppel] without proving he changed his position in reliance on the promise. Indeed, sometimes he recovers when it is fairly clear his position did not change." 11 Randy Barnett reported that scholars have formed "a new consensus that the doctrine of promissory estoppel is not primarily about compensating detrimental reliance." 12 A student author worried that, because courts focus on promise and not reliance, promisors can avoid liability by making unclear promises. ${ }^{13}$ The "new consensus" has even crossed international borders. ${ }^{14}$

Because of my surprise at the initial reports of the demise of reliance in promissory estoppel cases and at the acceptance of the thesis by other writers, I decided to examine all of the reported decisions in the United States in which a promissory estoppel claim succeeded or failed or in which promissory estoppel was discussed from July 1,1994 through June $30,1996 .{ }^{15}$ To study these cases systematically, I devised a coding sheet

9. See Yorio \& Thel, supra note 5, at 111 ("Judges actually enforce promises rather than protect reliance in Section 90 cases.").

10. See, e.g., Farber \& Matheson, supra note 7, at 909; Yorio \& Thel, supra note 5, at 112-14.

11. James Gordley, Enforcing Promises, 83 Cal. L. Rev. 547, 569 (1995).

12. Randy E. Barnett, The Death of Reliance, $46 \mathrm{~J}$. Legal Educ. 518, 522 (1996). Barnett further noted: "[Jay Feinman] fails to challenge the accuracy of the scholarship which contends that reliance is dead as a theory of promissory estoppel." Id. at 526.

13. See Joshua P. Rubin, Note, Take the Money and Stay: Industrial Location Incentives and Relational Contracting, 70 N.Y.U. L. Rev. 1277, 1288 (1995) (noting that because courts focus on promise, companies can "skirt liability by inducing reliance without making a clear promise"). For still other analyses that accept or give some credence to "the new consensus" about promissory estoppel, see Eisenberg, supra note 5, at 863; Jay M. Feinman, The Last Promissory Estoppel Article, 61 Fordham L. Rev. 303, 308 (1992).

14. See, e.g., Andrew Robertson, Situating Equitable Estoppel Within the Law of Obligations, 19 Sydney L. Rev. 32 (1997) (Australia).

15. The list of cases was compiled from a search on LEXIS of all cases within the time frame that mentioned "promissory estoppel." The two-part search run in the MEGA library and MEGA file was: "DATE (AFT 7/01/95 \& BEF 7/01/96) AND Promissory Estoppel" and "DATE (AFT 6/30/94 \& BEF 7/02/95) AND Promissory Estoppel." The search yielded 911 federal and state cases. From these, all cases which did not include a discussion of, or base a holding on, promissory estoppel were eliminated, yielding 362 cases that were then analyzed and coded. Cases reported by a LEXIS search of all cases 
that asked fifty-two questions about each case, including the subject matter of the dispute (employment, construction, etc.), the nature of the litigants (large commercial, sole proprietor, consumer, etc.), the procedural posture, whether the claim succeeded or failed, and the reasons courts gave for the success or failure. ${ }^{16}$ My research assistants then read and coded the cases. The picture of promissory estoppel cases that emerges is very different from the promise studies and the conclusions drawn from them. The data strongly demonstrate the crucial role reliance plays in courts' decisions either to deny or affirm a promissory estoppel claim at a preliminary motion or final judgment stage of a litigation. ${ }^{17}$ Moreover, the importance of reliance is consistent across variations in subject matter, the size and nature of the litigants, and the court rendering the judgment. The data also show that courts do not always choose expectancy damages. ${ }^{18}$ Finally, the data demonstrate the remarkable lack of success of promissory estoppel claims in reported decisions. ${ }^{19}$

This study also yields interesting related results that shed additional light on the nature of promissory estoppel, as we proceed into the twentyfirst century. For example, the data reveal the especial lack of success of promissory estoppel claims in employment cases. ${ }^{20}$ The study also underscores the long odds against winning a reversal on appeal of a decision against a recovery on promissory estoppel grounds, in sharp contrast to the near even chance of having a decision in favor of a recovery reversed on appeal. ${ }^{21}$

The methodology of the empirical portion of this study accepts courts' explanations for what they are doing as what they in fact are doing. This is obviously not a problem with respect to the win rates reported here. ${ }^{22}$ On the other hand, the accuracy and relevancy of the data on the judicial treatment of reliance depend respectively on the coders' ability to understand what a court states that it is doing and on a belief that judicial reasons are reliable and important.

Coder comprehension should not be a serious problem, however, because the coders were instructed to report only a court's explanation,

mentioning either the first or second Restatement section 90 but not "promissory estoppel" yielded only four additional cases, only one of which was clearly decided on promissory estoppel grounds. For convenience, some citations are to Westlaw.

16. The coded cases were entered into a computer database program and analyzed using Stata, Version 5.0. The results are on file with the Columbia Law Review.

17. See infra notes $82-90$ and accompanying text.

18. See infra notes $91-94$ and accompanying text.

19. See infra notes 57-81 and accompanying text.

20. See infra notes $66-77$ and accompanying text.

21. See infra notes $73-76$ and accompanying text.

22. Other problems with analyzing win-rate data are discussed infra notes 56-65 and accompanying text. 
and were not asked to look beyond the rhetoric. Moreover, many cases were reread to test the accuracy of the coders' initial conclusions. ${ }^{23}$

Assuming the accuracy of the coders, there are good reasons for paying attention to the reasons judges offer for their decisions. For one thing, the judges who tried the cases or heard the motions and read the briefs should know best what they required for success in the particular case and normally should be expected to account accurately for those requirements in their opinions. For another, a study that reports the reasons stated by the court cannot be criticized for manipulating the court's decision to reflect any "normative bias" of the authors. ${ }^{24}$ But the possibility remains that some judges, feeling handcuffed by the traditional elements of promissory estoppel that include detrimental reliance, or incapable of comprehending the lack of reliance in a case, sometimes talk reliance when the case belies its presence. Indeed, the premise of the promise studies was that such cases form the bulk of promissory estoppel cases. Even were this true, the data reported here would still be important because prospective litigants and legal analysts should understand and account for what courts say they are doing even if the courts are engaging in subterfuge or simply failing to understand the ramifications of their decisions.

This Article reports additional evidence of the importance of reliance, however, and suggests that judicial reasons are quite reliable in promissory estoppel cases. First, I analyze in depth, beyond the statistical results, a representative sample of the cases from the 1994-1996 data pool, both successful and unsuccessful for the party seeking a promissory estoppel recovery, to evaluate the reliability of the judicial reasons set forth. I find little evidence in successful cases that courts' finding of reliance is misleading. In addition, there is plenty of evidence in unsuccessful cases that courts are ready to dismiss promissory estoppel claims on the ground of lack of reliance, notwithstanding a serious promise or a promise made in the pursuit of economic activity. As a second check on the issue of the importance of reliance, I review the principal cases examined in the promise studies and conclude that a good argument can be made that reliance was important in those cases too.

Part I of this Article first briefly discusses the nature of promissory estoppel and then turns to the studies reporting reliance's demise. Part II presents and analyzes the empirical data from the 1994-1996 data pool. The data show the failure of promissory estoppel in the courts and the crucial role of reliance in court decisions. Part III looks more closely at a representative sample of the cases that constitute the data pool and concludes that the judicial focus on reliance is not misleading. Finally,

23. Over one-third of the cases were reread. I reread most of them during the process of writing Part III. Other cases were selected randomly for rereading.

24. Yorio and Thel acknowledged the problem of "normative bias," but believe their evidence is nonetheless "extensive and compelling." See Yorio \& Thel, supra note 5, at 115 n.20. 
Part IV reexamines the cases reported in the promise studies that have led others to pronounce the death of reliance. Part IV finds alternative explanations for many of these cases that preserve the role of reliance.

\section{Promissory Estoppel AND the Reports of the Demise of the RELIANCE REQUIREMENT.}

By the late nineteenth century, if not earlier, ${ }^{25}$ the most important basis for enforcing promises was the bargain theory of consideration. ${ }^{26}$ To be enforceable under the bargain theory, a promise had to be supported by consideration, meaning that the promisor would receive something in exchange for the promise. ${ }^{27} \mathrm{~A}$ bargain therefore consisted of "a negotiation resulting in the voluntary assumption of an obligation by one party upon condition of an act or forbearance by the other." 28 Under this definition, gratuitous promises, regardless of whether they induced reasonable detrimental reliance, were not enforceable. Because of the perceived injustice of such a result, ${ }^{29}$ courts began to enforce gift promises in various settings, such as where a promisee improved land in reliance on the owner's promise to convey it, and where a promisee failed to insure property in reliance on an insurance agent's promise to do so. ${ }^{30}$ Relying on such cases, Corbin persuaded the drafters of the first Restatement of Contracts to recognize justifiable reliance on gift promises as an independent theory of enforcement: ${ }^{31}$ "A promise which the promisor should reasonably expect to induce action or forebearance of a definite and substantial character on the part of the promisee and which does induce such action or forebearance is binding if unjustice can be avoided only by enforcement of the promise." 32

The theory of promissory estoppel, as section 90 came to be called, soon took hold and expanded. Courts began to enforce promises made as part of a bargain where the bargain was unenforceable on some technical ground, such as indefiniteness or the statute of frauds, but the prom-

25. See Richard E. Speidel, An Essay on the Reported Death and Continued Vitality of Contract, 27 Stan. L. Rev. 1161, 1162 (1975) (book review).

26. See Hillman, supra note 2, at 43.

27. See Restatement (Second) of Contracts $\$ 71$ (1981).

28. Baehr v. Penn-o-Tex Oil Corp., 104 N.W.2d 661, 665 (Minn. 1960).

29. Parties who rely on a promise experience more than disappointment when a promise is broken; reliance reduces their wealth. See Melvin Aron Eisenberg, Donative Promises, 47 U. Chi. L. Rev. 1, 18 (1979). "Is it not manifest that a person who has actually worsened his position by reliance on a promise has a more powerful case for redress than one who has not acted in reliance on the promise at all?" P.S. Atiyah, Contracts, Promises and the Law of Obligations, 94 L.Q. Rev. 193, 202 (1978).

30. See Restatement of Contracts $\S 90$ app. (Official Draft 1928) (explanatory notes).

31. See Jay M. Feinman, Promissory Estoppel and Judicial Method, 97 Harv. L. Rev. 678,683 (1984). Corbin was the reporter Williston's chief assistant. See Gilmore, supra note 1 , at $63-64$.

32. Restatement of Contracts $\S 90$ (1932). 
isee had relied on the promise. ${ }^{33}$ The creation of the formal theory of promissory estoppel and its proliferation did not go unnoticed, leading one commentator to note: "[T] he principle of section $90 \ldots$ has become perhaps the most radical and expansive development of the century in the law of promissory liability." ${ }^{4}$

Despite its solid foundation in judicial precedent and the clarity of the presentation of the theory of section 90 in both the first and second Restatement, ${ }^{35}$ promissory estoppel has been quite controversial. Most of the early quarrels, still unresolved today, involved the theory's uneasy coexistence with the bargain theory and whether one had "swallowed up" the other. ${ }^{36}$ Another debate arose in the 1980s with the publication of Farber and Matheson's, and later Yorio and Thel's, work on promissory estoppel. The issue was whether reliance or promise constituted the theory's conceptual core. As previously mentioned, the role of reliance was uncontroversial until the publication of these papers. Farber and Matheson captured the accepted wisdom they were addressing: " $[\mathrm{P}]$ romissory estoppel is one of the few points of agreement between the critical legal scholars on the left and the law and economics writers on the right. Both agree that reliance has been the foundation of promissory estoppel, and both accuse the courts of incoherence in applying the doctrine." ${ }^{37}$ Prior to the promise studies, then, it was settled as a descriptive matter that "detrimental reliance [was] the decisive factor" in promissory estoppel cases. ${ }^{38}$

In 1985, however, Farber and Matheson began to turn the accepted wisdom on its head. They read more than two hundred cases decided over a ten-year period and concluded that "reliance is no longer the key to promissory estoppel." 39 They believed that promissory estoppel cases could best be explained on grounds other than actual reliance. ${ }^{40}$ In their view, the determinative issue was whether a party with authority had made a "credible" promise and whether the promisor would benefit "from eco-

33. See Farber \& Matheson, supra note 7, at 907 ("[P]romissory estoppel is regularly applied to the gamut of commercial contexts."); id. at 908 n.20 ("Promissory estoppel is often invoked in cases in which non-substantive barriers to contractual recovery exist.").

34. Charles L. Knapp, Reliance in the Revised Restatement: The Proliferation of Promissory Estoppel, 81 Colum. L. Rev. 52, 53 (1981); see also Stanley D. Henderson, Promissory Estoppel and Traditional Contract Doctrine, 78 Yale L.J. 343 (1969) (tracing the proliferation of promissory estoppel).

35. But see Yorio \& Thel, supra note 5, at 129 (asserting differences between the first and second Restatement).

36. See Gilmore, supra note 1 , at 72 ; Knapp, supra note 34 , at 53 .

37. Farber \& Matheson, supra note 7, at 903-04.

38. Henderson, supra note 34 , at 364 . The debate, at least by the 1990 s, was also partly normative: Reliance proponents asserted the fairness of redressing detrimental reliance on a promise, whereas promise theorists focused on the liberty or moral value of enforcing promises. In this Article, I focus on the descriptive issue.

39. Farber \& Matheson, supra note 7, at 904 .

40. See id. at 903-06. 
nomic activity." 41 Courts enforced such promises to create in the promisee trust that the promisor would perform. ${ }^{42}$ This strategy encourages reliance in important contexts because promisees know they will be compensated if the promisor breaks the promise, ${ }^{43}$ but the particular promisee does not have to show actual reliance. Farber and Matheson concluded: "The role of reliance in establishing liability and determining damages in individual cases is on the decline-but reliance, in the form of trust, is on the rise as the policy behind legal rules of promissory obligation." 44

A few years later, Yorio and Thel published their study of promissory estoppel cases, most of which were cited by the first and second Restatements in section 90 . They concluded that "issues of both liability and remedy under section 90 turn on promise, not reliance." 45 Further, "the reported cases cannot be explained on the basis of reliance." 46 Instead, "[a] promise will be fully enforced ... if the promise is proven convincingly and is likely to have been serious and well considered when it was made." $\mathbf{4 7}$

Neither Farber and Matheson nor Yorio and Thel asserted that courts explicitly repudiate the reliance requirement in promissory estoppel cases. In fact, both sets of authors admitted that courts sometimes "adduce reliance as a reason for enforcing the promise," 48 and that courts may "feel constrained to speak the language of reliance." 49 Moreover, Farber and Matheson did "not claim that all the cases can be reconciled with the conclusion that detrimental reliance is no longer the key to promissory estoppel." ${ }^{\text {Do }}$ Nevertheless, the strong thrust of both articles was that issues other than reliance better explain most holdings and that the role of reliance is secondary at best. 51

Both sets of authors also reported that courts strongly favor expectancy damages over reliance damages as a remedy for promissory estop-

41. Id. at 914.

42. See id. at 905 .

43. See id. at 929. In the context of bargained exchanges, Lon Fuller wrote: "To encourage reliance we must therefore dispense with its proof." L. L. Fuller \& William R. Purdue, The Reliance Interest in Contract Damages, 46 Yale L.J. 52, 62 (1936).

44. Farber \& Matheson, supra note 7, at 929.

45. Yorio \& Thel, supra note 5 , at 167.

46. Id. at 161.

47. Id. at 113. Yorio and Thel's efforts were descriptive, although they surmised why promise was so important in a footnote. They suggested that courts may focus on promise because, on moral grounds, parties should keep their promises or because of the importance of autonomy. See id. at 166 n.363.

48. Id. at 159.

49. Farber \& Matheson, supra note 7, at 904 .

50. Id. at 914.

51. See id. at 903-05; Yorio \& Thel, supra note 5, at 158 ("Although courts sometimes give absence of reliance as a reason for refusing to enforce a promise under Section 90 , some other factor ... can usually explain the outcome."). 
pel, unless expectancy damages are unavailable for a technical reason. ${ }^{52}$ In fact, Yorio and Thel were quite adamant: "[T] he remedy for [promissory estoppel] is invariably expectancy relief (if measurable)...."53 The authors of the promise studies asserted that courts' preoccupation with expectancy relief is also evidence of the ascendancy of promise over reliance because the remedy substitutes for performance of the promise and does not simply remedy the harm done by reliance. ${ }^{54}$

As the Introduction to this Article relates, other authors now treat the Farber and Matheson and Yorio and Thel findings as "the new consensus": Although courts may use the language of reliance, actual reliance is unnecessary to enforce a claim of promissory estoppel.

\section{Promissory Estoppel: The Data Debunking the "New Consensus"}

This Part sets forth and analyzes the data. ${ }^{55}$ Section A presents data on win rates, which are relevant to the question of the importance of promissory estoppel as a theory of obligation. The data show a very low success rate of promissory estoppel claims. The data further show that this low success rate is not attributable to a single or a few subject areas or a single or a few contexts. The conclusion is therefore inescapable that promissory estoppel has not become the dominant theory for the enforcement of promises. Section B addresses the role of reliance in promissory estoppel cases. The data contradict the promise studies and illustrate the important role of reliance in both successful and unsuccessful cases applying promissory estoppel. Section $\mathrm{C}$ presents evidence on the remedial approach of courts. The data presented in the section demonstrate courts' flexibility in awarding either expectancy or reliance damages, thereby debunking the conclusion that courts favor expectancy damages in promissory estoppel cases.

\section{A. Win Rates}

There are, of course, many meanings of the word "win" or "success." A judgment for the plaintiff may be a "defeat" if the plaintiff expended more resources obtaining the judgment than the value of the judgment itself. Conversely, the plaintiff can claim success even if a court dismissed its claim if the litigation convinced the defendant to accede to the plaintiff's wishes.

The present analysis does not turn on such subtle measures of success. Here, there are two measures of success. First, a claim was success-

52. See Farber \& Matheson, supra note 7, at 909 (" $[R]$ ecent cases are heavily weighted towards the award of full expectation damages."); see also Mary E. Becker, Promissory Estoppel Damages, 16 Hofstra L. Rev. 131, 135 (1987) ("[C]ourts routinely award expectation damages unless those damages are too speculative, indefinite, or otherwise unavailable ....").

53. Yorio \& Thel, supra note 5 , at 166 (emphasis added).

54. See id. at 129-36.

55. For explanation of the data, see supra text accompanying notes 15-16. 
ful if the promissory estoppel claimant survived an opposing motion, whether or not the motion addressed the merits of the promissory estoppel claim. Second, as explained below, a much more accurate measure of success set forth here is success on the merits of the promissory estoppel claim. A claim succeeded on the merits if the promissory estoppel claimant won a judgment on the merits after a trial or on appeal after a trial, or won a motion for summary judgment at any level. ${ }^{56}$

1. General win rates. - Tables 1.1 and 1.2 show the generally low rate of success of promissory estoppel claimants. Table 1.1 sets forth the outcomes of all 362 cases, which include not only cases decided on the merits, but also cases in which the promissory estoppel claimant either successfully survived an opposing motion or failed on its own motion for summary judgment. Table 1.2 illustrates the outcomes of the 299 cases decided on the merits of the promissory estoppel claim. ${ }^{57}$

TABLE 1.1:

Win Rate of Promissory Estoppel Claims-All Court LevelsOutcome of All CASES

\begin{tabular}{|l|r|r|}
\hline Outcome of Case & $\underline{\mathrm{N}}$ & $\underline{(\underline{\%})}$ \\
\hline Claim succeeded on the merits & 29 & $(8.01)$ \\
\hline Claim failed on the merits & 270 & $(74.59)$ \\
\hline Claim survived an opposing motion & 57 & $(15.74)$ \\
\hline Claimant motion for summary judgment denied & 3 & $(0.83)$ \\
\hline Cross-motions for summary judgment denied & 3 & $(0.83)$ \\
\hline Total & 362 & \\
\hline
\end{tabular}

56. A few cases were borderline as to whether success was on a promissory estoppel theory. See, e.g., In re Marriage of Yanda, 528 N.W.2d 642, 644 (Iowa 1994), where the court found that equitable estoppel barred a spouse from collecting child support. The court appeared to use promissory and equitable estoppel interchangeably. For purposes of this study, such cases were counted as successes.

57. The procedural breakdown of the 29 cases successful on the merits was:

Trial court

Summary judgment 1

Bench trial $\quad 5$

Appellate court

Affirmed summary judgment $\quad 1$

Affirmed jury decision $\quad 8$

$\begin{array}{lr}\text { Affirmed bench trial decision } & 8\end{array}$

$\begin{array}{ll}\text { Reversed administrative court decision } & 1\end{array}$

$\begin{array}{ll}\text { Reversed bench trial decision } & 1\end{array}$

Highest court

Affirmed bench trial decision 2

Affirmed summary judgment 1

Affirmed trial court approved 1

arbitration award 
TABLE 1.2:

Win Rate of Promissory Estoppel Claims-All Court LevelsOutcome of Cases Decided On the Merits

\begin{tabular}{|l|c|c|}
\hline Outcome of Case & $\underline{N}$ & $\underline{\%}$ \\
\hline Claim succeeded on the merits & 29 & $(9.70)$ \\
\hline Claim failed on the merits & 270 & $(90.30)$ \\
\hline Total & 299 & \\
\hline
\end{tabular}

Table 1.1 shows that promissory estoppel claims succeeded on the merits in $8.01 \%$ of the reported cases and succeeded by surviving an opposing motion in $15.74 \%$ of the reported cases, for a total win rate of $23.75 \%$. Even this seemingly low win rate is inflated. Counting the full 57 claims surviving a motion as successes inflates the total win rate for at least two reasons. First, as is discussed more fully in Part III, many of these cases involved claimants fighting off a summary judgment motion. Courts are generally more willing to find the elements of promissory estoppel when the party asserting the claim need only establish the existence of factual issues. ${ }^{58}$ In fact, courts sometimes intimate that they do not expect the promissory estoppel claim ultimately to be successful..$^{59}$ Second, several of the 57 cases involved issues on appeal that ultimately did not concern the elements of promissory estoppel. ${ }^{60}$ For these reasons, the most accurate measure of success and failure may be gained by comparing success and failure rates on the merits. Table 1.2 does this and shows that only $9.70 \%$ of promissory estoppel claims that reached a decision on the merits of the claim were successful.

One way of comprehending the meaning of the promissory estoppel win rates is to consider the prediction of theorists studying win rates that each side should win about $50 \%$ of the time. ${ }^{61}$ This is because parties should settle claims heavily favoring one of them to save costs, and litigate close cases where the parties cannot predict the outcome. ${ }^{62}$ Perhaps a

58. See infra notes 113-116 and accompanying text.

59. See, e.g., Miller v. Taylor Insulation Co., 39 F.3d 755, 759 (7th Cir. 1994) (evidence presented questions of fact sufficient to defeat a motion for summary judgment; nevertheless, "maybe [employee] should have questioned whether he was really being promised [a] benefit"); Leblanc v. United Parcel Serv., Inc., No. 2:95-CV-68, 1996 WL 192011, at *5 (D. Vt. Apr. 2, 1996) ("The Court cannot find "to a certainty ... that no relief can be granted under any set of facts that might be proved in support of' the claims." (quoting De La Cruz v. Tormey, 582 F.2d 45, 48 (9th Cir. 1978))).

60. See, e.g., Brace v. City of Lakewood, 899 P.2d 301, 305 (Colo. Ct. App. 1995) (premature appeal from interlocutory order), rev'd, 919 P.2d 231 (Colo. 1996); CSO Servicing Corp. v. City of Eau Claire, 536 N.W.2d 731, 734 (Wis. Ct. App. 1995) (statute pertaining to removal of buildings not the exclusive remedy).

61. See, e.g., George L. Priest \& Benjamin Klein, The Selection of Disputes for Litigation, $13 \mathrm{~J}$. Legal Stud. 1, 4-5 (1984).

62. This "case-selection effect" is discussed in Kevin M. Clermont \& Theodore Eisenberg, Do Case Outcomes Really Reveal Anything About the Legal System? Win Rates 
better understanding of the meaning of the promissory estoppel win rates can be gained by comparing them to actual win rates of other related cases, such as other contract cases. Although data comparable to this study are not available for contract cases, published information offers at least a rough basis for comparison. Table 1.3 compares win rates on the merits of promissory estoppel cases in federal district courts and state trial courts with win rates of contract claims in federal district courts and shows that the contract claims were 10 times more successful. ${ }^{63}$

TABLE 1.3:

Win Rate of Promissory Estoppel Claims on the MeritsTrial Courts

\begin{tabular}{|l|r|r|r|r|r|}
\hline & \multicolumn{2}{|c|}{$\begin{array}{c}\text { Plaintiff } \\
\text { Wins }\end{array}$} & \multicolumn{2}{c|}{$\begin{array}{c}\text { Plaintiff } \\
\text { Loses }\end{array}$} & \\
& \multicolumn{1}{|c|}{$\mathrm{N}$} & $\underline{(\%)}$ & $\underline{\mathrm{N}}$ & $\underline{\underline{(\%)}}$ & Total \\
\hline $\begin{array}{l}\text { Promissory Estoppel } \\
\text { Claims64 }\end{array}$ & 6 & $(5.45)$ & 104 & $(94.55)$ & 110 \\
\hline $\begin{array}{l}\text { Comparison: Win Rates } \\
\text { for Contract Claims in } \\
\text { Federal District Court } \\
\text { Cases }\end{array}$ & & & & & \\
\hline
\end{tabular}

2. Lack of success in all subject areas and contexts, and the special problem of employment contracts. - Table 2.1 breaks out the win rates on the merits for the different subject matters and illustrates the lack of success of promissory estoppel across all subject areas. The Table also highlights

and Removal Jurisdiction 7-8 (Aug. 25, 1997) (unpublished manuscript, on file with the Columbia Law Review) ("[C]ase-selection effect theory holds that the win rate reveals something about the set of adjudged cases, and not much about the underlying mass of disputes .....").

63. But neither the general prediction of $50 \%$ win rates nor the data set forth in Table 1.3 addresses wins and losses of individual claims in a multiple-claim law suit. In fact, promissory estoppel is almost invariably joined by other claims, which may help account for the low win rate. See infra text accompanying notes 80-81.

64. These state trial court and federal district court claims from the data were successful or failed on the merits, as defined supra in text accompanying note 56 .

65. These data are derived from a "database of about 3.7 million federal district court civil cases terminated over the last 17 fiscal years. The data were gathered by the Administrative Office of the United States Courts, assembled by the Federal Judicial Center, and disseminated by the Inter-university Consortium for Political and Social Research." Quoting from the Internet at <http://teddy.law.cornell.edu:8090/ questcv2.htm> (visited Feb. 3, 1998) (on file with the Columbia Law Review) where the data is available. The plaintiff win rate reported in this Table is for all types of contract cases terminated in federal district courts during fiscal years 1990-1994 (July 1, 1989 through September 30, 1994) for which the method of disposition was a pre-trial motion, jury verdict, directed verdict, or non-jury trial. Cases that were disposed of by default judgment or consent judgment are not included. 
the high frequency of employment cases (142 out of 299 cases or $47 \%$ ), but shows the startling lack of success on the merits of these cases. ${ }^{66}$ Claimants won only $4.23 \%$ of the employment cases decided on the merits. Table 2.2 shows that general win rates of all other subject areas combined were $14.65 \% .{ }^{67}$ The difference in win rates between employment and non-employment cases is statistically significant. ${ }^{68}$

A reexamination of the 1994-1996 employment cases revealed nothing unusual that would explain the low win rate. It appears that claimants in such cases simply have been unable to jump the traditional hurdles necessary for success, including proving a distinct promise and the reasonableness of relying on statements in employee handbooks or representations by employer agents. ${ }^{69}$ Perhaps employee claimants, encouraged by earlier favorable judicial outcomes in analogous settings, did not perceive a judicial retrenchment from creating employee rights that may have begun in the 1990 s. $^{70}$

66. In addition, claimants won none of the 13 cases decided on the merits involving loan agreements.

67. If cases where claimants survived an opposing motion are included, claimants won $17.47 \%$ of employment cases, whereas general win rates of all other subject areas combined were $29.08 \%$.

68. These Tables explore the postulate that employment and other promissory estoppel cases have the same success rate. This hypothesis is called the null hypothesis. See George W. Snedecor \& William G. Cochran, Statistical Methods 64 (8th ed. 1989). The significance levels set forth (also called p-values, and calculated by a two-sided Fisher's exact test) are "the probability of rejecting the null hypothesis when it is . . true." Kevin M. Clermont \& Theodore Eisenberg, Xenophilia in American Courts, 109 Harv. L. Rev. 1120,1127 n.17 (1996). Put another way, the significance levels provide an inverse measure of the likelihood that the difference in win rates between employment and nonemployment cases sets forth a real instead of a random variation. Thus, a p-value of 0.05 means that there is a $95 \%$ probability that the difference in win rates reflects a real difference and is not due to random variation. See id. By convention, statistically significant results are at or below the .05 level. See id. (citing The Evolving Role of Statistical Assessments As Evidence in the Courts 197 (Stephen E. Fienberg ed., 1989)).

69. See also infra notes 77-81 and accompanying text.

70. See Katherine Van Wezel Stone, Mandatory Arbitration of Individual Employment Rights: The Yellow Dog Contract of the 1990s, 73 Denv. U. L. Rev. 1017, 1030-34, 1049-50 (1996) (employees forced to utilize employer-created arbitration systems). 
TABLE 2.1:

Win Rates of Promissory Estoppel Clatms by Subject MatterOutcome of Cases Decided on the Merits

\begin{tabular}{|l|r|r|r|}
\hline & \multicolumn{2}{|c|}{$\begin{array}{c}\text { PE claim } \\
\text { succeeded } \\
\text { on the } \\
\text { merits }\end{array}$} & \\
Subject Matter of Dispute & \multicolumn{2}{|c|}{${ }^{\text {(\%) }}$} & Total \\
\hline Employment & 6 & $(4.23)$ & 142 \\
\hline Construction & 2 & $(22.22)$ & 9 \\
\hline Sale of Real Property & 1 & $(10.00)$ & 10 \\
\hline Lease of Real Property & 0 & $(0.00)$ & 4 \\
\hline Loaning of Funds & 0 & $(0.00)$ & 13 \\
\hline Sale of Goods & 4 & $(22.22)$ & 18 \\
\hline Sale of Intangibles & 0 & $(0.00)$ & 4 \\
\hline Lease of Equipment & 1 & $(33.33)$ & 3 \\
\hline Promissory Note & 0 & $(0.00)$ & 5 \\
\hline Other & 15 & $(16.85)$ & 89 \\
\hline Unclear & 0 & $(0.00)$ & 2 \\
\hline Total & 29 & $(9.70)$ & 299 \\
\hline
\end{tabular}

TABLE 2.2:

Win Rates of Promissory Estoppel Claims in Which Subject Matter Was Employment-Outcome of Cases Decided on the Mertts

\begin{tabular}{|l|r|r|c|}
\hline & \multicolumn{2}{|c|}{$\begin{array}{c}\text { PE claim } \\
\text { succeeded } \\
\text { on the } \\
\text { merits }\end{array}$} & \\
Subject Matter of Dispute & \multicolumn{2}{|c|}{ N } & \multicolumn{1}{|c|}{} \\
\hline \hline Employment & \multicolumn{1}{|c|}{ Total } \\
\hline All Other Subject Matter & 23 & $(4.23)$ & 142 \\
\hline Total & 29 & $(9.70)$ & 299 \\
\hline
\end{tabular}

Fisher's exact test (2-sided) $\mathrm{p}=0.003$

Table 2.3 next shows the win rate on the merits of promissory estoppel claims by the context in which the alleged promise was made. The Table highlights the lack of success of promissory estoppel claims in the context of employment at will, a subcategory of the employment cases. As with the larger employment subject matter, employment-at-will 
promissory estoppel cases succeeded on the merits at a minuscule level, only $4.12 \% .{ }^{71}$ Table 2.3 also shows that the total win rate on the merits for claimants in the business context (excluding employment at will) was $12.40 \%$, only slightly higher than the overall average win rate on the merits of $9.70 \% .72$

TABLE 2.3:

Win Rates of Promissory Estoppel Claims by Context of Alleged Promise-Outcome of Cases Decided on the Meruts

\begin{tabular}{|l|r|r|r|}
\hline & \multicolumn{2}{|c|}{$\begin{array}{c}\text { PE claim } \\
\text { succeeded } \\
\text { on the } \\
\text { merits }\end{array}$} & \\
\hline Eontext of Alleged Promise & \multicolumn{2}{|c|}{ N $\%$ Tot } & Total \\
\hline Employment at will & 4 & $(4.12)$ & 97 \\
\hline Business & 16 & $(12.40)$ & 129 \\
\hline Non-business & 1 & $(11.11)$ & 9 \\
\hline Agreement to agree & 1 & $(7.14)$ & 14 \\
\hline Other & 6 & $(14.29)$ & 42 \\
\hline Unclear & 1 & $(12.50)$ & 8 \\
\hline Total & 29 & $(9.70)$ & 299 \\
\hline
\end{tabular}

3. Reversal rates on review. - The final Tables on win rates display the striking results of what happens to promissory estoppel claims upon appellate review. Table 3.1 shows that parties bringing a promissory estoppel claim who won in lower courts had their victories overturned in appellate courts on the merits $43.24 \%$ of the time, whereas parties defending against a promissory estoppel claim who won below were reversed in appellate courts on the merits less than $2 \%$ of the time.

71. In dispositions not limited to the merits, employment-at-will claims succeeded at about a $12 \%$ rate compared with a $17 \%$ rate for all employment cases.

72. Claimants won 16 of 129 such cases according to Table 2.3. The business context includes all cases in which at least one of the parties was seeking to earn a profit (with the exception of employment-at-will and agreement-to-agree cases, which are separate categories). 
TABLE 3.1:

Reversal Rates upon Appeliate Review-Outcome of Cases DECIDED ON THE MERITS

\begin{tabular}{|l|r|r|r|}
\hline & \multicolumn{2}{|c|}{$\begin{array}{c}\text { Reversal } \\
\text { Rate }\end{array}$} & \\
Party that won below & \multicolumn{2}{|c|}{ (\%) } & Total \\
\hline Promissory estoppel claimant & 16 & $(43.24)$ & 37 \\
\hline Promissory estoppel opponent & 2 & $(1.32)$ & 151 \\
\hline
\end{tabular}

Fisher's exact test (2-sided) $\mathrm{p}=0.000$

The reversal rates set forth in Table 3.1 add in two ways to the evidence of the low odds of ultimate success on promissory estoppel grounds. First, studies have demonstrated that "[a]ppellate courts tend to affirm lower courts" in part because of the deference that appellate procedural rules pay to fact-findings below. ${ }^{73}$ Yet reversal rates generally are much higher than $2 \%$. In fact, one study of over a thousand published product liability cases decided from 1983 through 1988 showed that plaintiffs who won in lower courts lost on appeal in $34.3 \%$ of cases, whereas defendants who won below lost $37.4 \%$ of the time on appeal. ${ }^{74}$ With a success rate of only $1.32 \%$, promissory estoppel claimants are much less likely than most plaintiffs to reverse their trial court losses. ${ }^{75}$

Second, the asymmetry between the ability of promissory estoppel claimants and their opponents to obtain reversals is striking. The products liability data suggest a tendency to reverse (about one-third of the time) that is roughly equal between plaintiffs and defendants. In promissory estoppel cases, however, losing defendants obtain reversals in all cases at a rate more than thirty times that of losing claimants. The Tables show this difference to be highly statistically significant. ${ }^{76}$

4. Conclusions. - As a whole, the win-rate data strongly suggest that promissory estoppel has not subsumed or even overshadowed other theories of promise enforcement in the courts. The win-rate data establish that promissory estoppel was very unsuccessful in reported decisions during 1994-1996 across a variety of subject matters and contexts. Further, even if they manage to succeed below, promissory estoppel claimants run a real risk of reversal on appeal. And promissory estoppel claimants in the employment setting are even more likely to lose than claimants in other areas.

73. Theodore Eisenberg \& James A. Henderson, Jr., Products Liability Cases on Appeal: An Empirical Study, Just. Sys. J., 1993 vol. 16, No. 2, at 117, 126.

74. See id.

75. Again remember, however, that promissory estoppel claims are brought with other claims that may or may not have been successful on appeal. See supra note 63 and accompanying text.

76. See supra note 68 and accompanying text. 
The win-rate data provide no direct evidence of the role and effect of promissory estoppel in a transactor's ordinary course of dealing and in the settlement of disputes before or during litigation. Nevertheless, people's perceptions about the success of promissory estoppel claims in the courts surely influence their decisions outside of litigation. For example, the possibility cannot be ruled out that in the mid-1990s promissory estoppel claimants received generous settlements before a decision in litigation because litigants wrongly perceived that the theory was highly successful in the courts. If true, promissory estoppel was more "successful" as a theory in the mid-1990s than reported cases indicate. Nevertheless, the rate of favorable settlement should decrease as evidence of judicial resistance to the theory becomes more widely known.

The lingering question is, of course, why is promissory estoppel not faring well in the courts? Although win-rate data analysis is a growing field, ${ }^{77}$ I will offer only some preliminary perspectives here. One possible explanation for the low win rate is that parties miscomprehended the nature of promissory estoppel. Although the theory of promissory estoppel still receives wide publicity as a principal basis for promise enforcement, ${ }^{78}$ the rhetoric may no longer reflect the reality of judicial attitudes toward the theory. Parties in the mid-1990s simply may not have comprehended a judicial souring on the theory, which is consistent with courts' recent reluctance to intervene in the contracting process on other grounds. ${ }^{79}$ Such parties might therefore fail to settle what they should have predicted as likely wins for defendants (but did not).

Another possible explanation for the low win rate is that claimants are bringing weak promissory estoppel claims and not making an effort to settle them. Claimants may bring promissory estoppel claims only as subsidiary theories tacked on to a contract or other claim, sometimes even as an afterthought. The abstract call for "justice" in the second Restatement's definition of promissory estoppel may add to the allure of "throwing in" the claim. ${ }^{80}$ Evidence supporting this explanation comes from examining the tenuous nature of many of the claims in the multitude of cases in which promissory estoppel failed. ${ }^{81}$

77. See, e.g., Clermont \& Eisenberg, supra note 68.

78. See, e.g., Eric Mills Holmes, The Four Phases of Promissory Estoppel, 20 Seattle U. L. Rev. 45 (1996).

79. The apparent diminishing role of good faith in the courts supports this explanation. See Richard E. Speidel, The "Duty" of Good Faith in Contract Performance and Enforcement, 46 J. Legal Educ. 537, 541-42 (1996); see also Ralph James Mooney, The New Conceptualism in Contract Law, 74 Or. L. Rev. 1131 (1995) (noting a widespread shift in the application of contract law by courts abandoning strong interventionist principles in favor of "classical" principles of contract law).

80. See Restatement (Second) of Contracts $\$ 90$ (1981).

81. See infra Part III. A Michigan judge may best have captured the nature of losing claims when the judge pointed out to a claimant: "None of the cases cited . . . in support of [the] promissory estoppel claims apply to the instant facts. ... [I]ndeed, in only one of these cases was $\mathrm{a}[\mathrm{n}]$. . . estoppel argument allowed to proceed." Forest Park Assocs. v. 


\section{B. The Role of Reliance in Promissory Estoppel Cases}

Despite the promise theorists' reports of the waning of reliance in promissory estoppel cases, the data, consisting of both successful and unsuccessful cases, show the crucial role reliance played in the 1994-1996 cases.

1. Reliance as a reason for success. - Table 4.1, which includes all the successful promissory estoppel cases, on the merits or otherwise, explores the rate at which such cases discuss reliance. It shows the high rate of courts discussing reliance as a reason for success on the merits $(93.10 \%)$ and for surviving an opposing motion $(56.14 \%)$. Moreover, a discussion of reliance as a reason means that the court did more than merely state in one sentence or so that reliance is an element of promissory estoppel. A discussion means that the court specifically looked for and found reliance in the facts of the case.

TABLE 4.1:

Reliance as a Reason for the Success of Promissory Estoppel ClaIMS

\begin{tabular}{|l|c|c|c|}
\hline & \multicolumn{2}{|c|}{$\begin{array}{c}\text { Reliance } \\
\text { discussed as } \\
\text { a reason }\end{array}$} & \\
& \multicolumn{2}{|c|}{$\underline{\underline{\mathbf{N}}}$} & Total \\
\hline PE claim succeeded on the merits & 27 & $(93.10)$ & 29 \\
\hline PE claim survived opposing motion & 32 & $(56.14)$ & 57 \\
\hline Total & 59 & $(68.60)$ & 86 \\
\hline
\end{tabular}

As mentioned in Part I and discussed in Part IV, the promise studies concede that courts still speak the language of reliance. At a minimum, the data in Table 4.1 confirm this. Part III, which looks more closely at the successful cases, shows that courts not only invoke reliance, but that reliance is actually present.

As discussed further in Part III, the two cases where the promissory estoppel claimant succeeded on the merits but the court failed to mention reliance do not stand for the proposition that a promissory estoppel claim can succeed without reliance. Both were appellate court decisions that simply involved different issues. ${ }^{82}$ Nor do the 25 cases in which a claimant survived an opposing motion but the court did not discuss reliance show that reliance is unnecessary. These cases generally

Swartz, No. 93-CV-74327-DT, 1994 U.S. Dist. Lexis 19047, at *35 n.12 (E.D. Mich. Nov. 10, 1994) (citations omitted).

82. See Lyons v. Teamsters Local Union No. 961, 903 P.2d 1214 (Colo. Ct. App. 1995); Kemira, Inc. v. Williams Investigative \& Sec. Serv., Inc., 450 S.E.2d 427 (Ga. Ct. App. 1994); infra notes $111-112$ and accompanying text. 
involved issues other than promissory estoppel, ${ }^{83}$ or uncontested reliance claims, ${ }^{84}$ or the court's assumption that reliance existed..$^{85}$ None of the 25 cases found for the promissory estoppel claimant after noting the absence of reliance.

2. Reasons for failure. - Table 5.1, which includes all the unsuccessful promissory estoppel cases on the merits, shows the reasons courts gave for the failure of a promissory estoppel claim. Percentages are omitted because courts often gave multiple reasons. The Table demonstrates that courts reject promissory estoppel claims on a wide variety of grounds and do not focus exclusively, or even in a clear preponderance of cases, on questions involving the promise. ${ }^{86}$ Although courts most often discuss the lack of a definite promise as a reason for failure, this justification does not mean that it is the only important factor even in those cases. Because each element of promissory estoppel is a prerequisite for recovery, it would not be unusual or telling that some courts that reject promissory estoppel claims never get to the issue of reliance, or to the issue of promise for that matter.

83. See, e.g., Brace v. City of Lakewood, 899 P.2d 301, 304-05 (Colo. Ct. App. 1995) (promissory estoppel claim not barred by sovereign immunity), rev'd, 919 P.2d 231 (Colo. 1996); CSO Servicing Corp. v. City of Eau Claire, 536 N.W.2d 731, 733-34 (Wis. Ct. App. 1995) (exclusive statutory remedy did not bar promissory estoppel claim).

84. See, e.g., Decker v. Andersen Consulting, 860 F. Supp. 1300, 1309 (N.D. Ill. 1994) (after listing the elements required to establish a promissory estoppel claim, including reliance, the court noted that the "only element in dispute is whether [the promisor's] statements . . constitute an unambiguous promise").

85. See, e.g., Shelley v. Trafalgar House Pub. Ltd., 918 F. Supp. 515, 523 (D.P.R. 1996) ("If there was reliance, Plaintiffs may have potentially sustained an injury.").

86. The "another reason" category of cases in Table 5.1 consists of a hodgepodge of reasons, most unrelated to either promise or reliance, such as preemption by federal law, preemption by a written contract, procedural irregularities, and failure to recognize promissory estoppel as a viable theory in the particular context (often employment at will). A few cases employ reasons that are arguably promise or reliance related, such as the promisor's lack of authority. 
TABLE 5.1:

Reasons for Failure of Promissory Estoppel Clatms-

CASES Decided ON THE MERTtS

\begin{tabular}{|l|r|}
\hline There was no definite promise & 129 \\
\hline The promise was ambiguous & 28 \\
\hline It would be unjust to enforce the promise & 8 \\
\hline Reliance was not reasonable & 86 \\
\hline There was no detrimental reliance & 76 \\
\hline Reliance was unforeseeable & 15 \\
\hline Reliance was too speculative & 6 \\
\hline Reliance was not induced by the other party & 23 \\
\hline The statute of frauds barred recovery & 32 \\
\hline $\begin{array}{l}\text { The parol evidence rule made evidence of a promise } \\
\text { inadmissible }\end{array}$ & 8 \\
\hline Another reason discussed for the failure of the claim & 73 \\
\hline Reason for failure of claim unclear & 5 \\
\hline
\end{tabular}

Table 5.2 groups the reliance-related reasons for failure of a promissory estoppel claim (no detrimental reliance, reliance was not reasonable, reliance was unforeseeable, reliance was too speculative, or reliance was not induced by the other party) and labels them "defects in reliance." The Table shows that in cases where promissory estoppel failed on the merits, one or more reasons relating to a defect in reliance were discussed in more than half the cases ( 151 cases or $55.93 \%$ ). In fact, in 68 of the 151 cases, the court failed to discuss any promise-related reason (no definite promise, promise was ambiguous, or unjust to enforce the promise). It is worth repeating that these figures do not suggest that reliance was unimportant in cases that did not discuss it; only that the court found another defect in the claim, often a defect in the promise, ${ }^{87}$ and did not have to proceed to a reliance analysis. Overall, the picture that emerges is that neither promise nor reliance dominates as a judicial reason for the failure of promissory estoppel claims. Rather, both elements are crucial to recovery.

87. One or more reasons constituting a defect in the promise were discussed in half of the cases (135 cases). The court failed to discuss a defect in reliance in only 52 of those cases. 
TABLE 5.2:

A Defect in Reliance as a Reason for failure of Promissory Estoppel Claims-CAses Decmed on the Merits

\begin{tabular}{|l|c|c|c|}
\hline & $\underline{N}$ & $\underline{(\%)}$ & Total \\
\hline Defect in reliance discussed & 151 & $(55.93)$ & 270 \\
\hline $\begin{array}{l}\text { Defect in reliance discussed } \\
\text { and defect in promise not discussed }\end{array}$ & 68 & $(25.19)$ & 270 \\
\hline
\end{tabular}

3. Reasons for failure by subject matter. - Table 6.1 shows the frequency of the use of defective reliance as a reason for the failure of claims over the range of subject matters. The Table illustrates that courts' responses are relatively consistent over these subject matters. In the two sizeable categories, employment and other, a defect in reliance was discussed in more than $50 \%$ of the cases.

TABLE 6.1:

A Defect in Reliance as a Reason for Failure on the Mertis of Promissory Estoppel Claims-By Subject Matter

\begin{tabular}{|l|r|r|r|}
\hline & \multicolumn{2}{|c|}{$\begin{array}{c}\text { Defect in } \\
\text { reliance } \\
\text { discussed }\end{array}$} & \\
Subject Matter of Dispute & \multicolumn{2}{|c|}{ N } & Total \\
\hline Employment & 81 & $(59.56)$ & 136 \\
\hline Construction & 4 & $(57.14)$ & 7 \\
\hline Sale of Real Property & 6 & $(66.67)$ & 9 \\
\hline Lease of Real Property & 1 & $(25.00)$ & 4 \\
\hline Loaning of Funds & 5 & $(38.46)$ & 13 \\
\hline Sale of Goods & 5 & $(35.71)$ & 14 \\
\hline Sale of Intangibles & 2 & $(50.00)$ & 4 \\
\hline Lease of Equipment & 0 & $(0.00)$ & 2 \\
\hline Promissory Note & 2 & $(40.00)$ & 5 \\
\hline Other & 45 & $(60.81)$ & 74 \\
\hline Unclear & 0 & $(0.00)$ & 2 \\
\hline Total & 151 & $(55.93)$ & 270 \\
\hline
\end{tabular}

Not included in Table 6.1, but relevant to the question of the role of reliance in promissory estoppel cases, is the relatively high number of claims that fail in the business context at least in part because of a defect 
in reliance, namely about $48 \%$ (54 out of 113 cases). ${ }^{88}$ The figures were roughly comparable, but not quite as high, for reasons constituting a defect in the promise. ${ }^{89}$ These figures cast doubt on Farber and Matheson's thesis that courts are inclined to enforce promises "made in furtherance of an economic activity." 90 If courts were generally enforcing such promises without more, one would expect to see cases failing in the business context (by definition "economic activity") predominantly because of a defect in the promise. The result here should not be surprising if both promise and reliance are prerequisites for recovery on promissory estoppel grounds. Courts simply focused on one or the other element, found it wanting, and terminated the case.

\section{Promissory Estoppel Remedies}

Despite the findings of the promise theorists that, when measurable, courts "invariably" award expectancy damages in successful promissory estoppel cases, ${ }^{91}$ the evidence was not so clear in the 1994-1996 cases. Table 7.1 sets forth the nature of the awards granted by courts in successful promissory estoppel cases. The data tend to show that in 1994-1996 courts were flexible in their awards, sometimes awarding expectancy in the form of damages or specific performance and sometimes awarding reliance damages. Moreover, litigants appeared to believe that either remedy was available in making their claims.

Table 7.1 is inconclusive, however, for several reasons. First, it is often difficult to determine the nature of the remedy awarded. In general, courts seem to take less care in discussing the remedies for successful promissory estoppel claims than in considering the elements of the doctrine. Second, Table 7.1 is only suggestive because courts often talk expectancy or reliance in situations where the remedies are identical. ${ }^{92}$ Third, some appellate decisions affirm promissory estoppel claims, but the remedies granted appear to be based on another theory of recovery. ${ }^{93}$ Finally, the remedial approach of the courts is inconclusive because

88. The 113 cases do not include employment-at-will and agreement-to-agree claims. See supra Table 2.3. For a definition of the business context, see supra note 72. $38 \%$.

89. A defect in the promise was a reason for failure in 43 out of 113 cases, or about

90. Farber \& Matheson, supra note 7, at 905.

91. See Yorio \& Thel, supra note 5 , at $151,166$.

92. See, e.g., Percy J. Matherne Contractor, Inc. v. Grinnell Fire Protection Sys. Co., 915 F. Supp. 818, 826 (M.D. La. 1995), aff'd, 102 F.3d 550 (5th Cir. 1996); Speech Tech. Assocs. v. Adaptive Comm. Sys., Inc., No. C-88-2392-VRW, 1994 WL 449032, at *13 (N.D. Cal. Aug. 16, 1994); infra notes 162-165 and accompanying text.

93. See, e.g., Speech Tech., 1994 WL 449032, at *13 (misappropriation of trade secrets); VMark Software, Inc. v. EMG Corp., 642 N.E.2d 587, 597 (Mass. App. C. 1994) (misrepresentation). 
courts sometimes appear to restrict the recovery to that requested by the claimant, either reliance or expectancy. ${ }^{94}$

TABLE 7.1:

Type of Damages Awarded in Promissory Estoppel Clatms

SUCCESSFUL ON THE MERITS

\begin{tabular}{|l|r|c|}
\hline & $\underline{N}$ & $\underline{\%}$ \\
\hline Court awarded reliance damages & 7 & $(24.14)$ \\
\hline Court awarded expectancy damages & 7 & $(24.14)$ \\
\hline Court awarded specific performance & 1 & $(3.45)$ \\
\hline Unclear what was awarded & 9 & $(31.03)$ \\
\hline $\begin{array}{l}\text { No damages awarded (injunctive relief or } \\
\text { defensive use of promissory estoppel) }\end{array}$ & 5 & $(17.24)$ \\
\hline Total & 29 & \\
\hline
\end{tabular}

III. Reliance in the Cases: A Closer Look

To capture the flavor of the role of reliance in the 1994-1996 cases, this Part discusses representative cases. Section A analyzes cases where the promissory estoppel claim succeeded on the merits. ${ }^{95}$ Section B looks at cases where the promissory estoppel claim survived an opposing motion. Finally, Section C examines cases where the promissory estoppel claim failed. In each category, the goal is to evaluate not only what courts said they were doing, but also to see what role reliance actually played. Contrary to the conclusions of the promise studies, the cases reveal that reliance plays an indispensable role in promissory estoppel cases. In fact, courts' enthusiasm for delving into the question of reliance probably contributes to the relatively low level of success of the promissory estoppel theory in the courts. Perhaps Judge Posner said it best: "A promise . . . does not by itself a promissory estoppel make. The promisee must rely to his detriment, and his reliance must be reasonable . . ."96

\section{A. Cases Successful on the Merits}

1. Reliance discussed as a reason for success. - Overall, courts discussed the need for reliance in 27 of 29 promissory estoppel cases successful on 1995).

94. See, e.g., Cyberchron Corp. v. Calldata Sys. Dev., Inc., 47 F.3d 39, 46 (2d Cir.

95. For a definition of "on the merits," see supra text accompanying note 56.

96. Miller v. Taylor Insulation Co., 39 F.3d 755, 759 (7th Cir. 1994). Judge Posner reversed a summary judgment in favor of Taylor where Taylor allegedly broke a promise to provide Miller group health insurance while he worked as a consultant for Taylor. Posner wrote that: "Miller must show that, had it not been for the promise, he would have obtained comparable medical insurance, and he must further show that he was reasonable in believing that he was covered by the medical reimbursement plan." Id. 
the merits. ${ }^{97}$ Not only did the courts look for reliance in successful cases, but the reliance they found was concrete and real. Typical cases included a general contractor making a bid for a renovation job in reliance on a subcontractor's bid to install the roof, ${ }^{98}$ a company spending more than $\$ 75,000$ to erect a sign in reliance on a state's approval of the location, ${ }^{99}$ and a stockbroker purchasing bonds for resale in reliance on an investor's promise to buy the bonds. ${ }^{100}$

The cases also suggest the indispensability of detrimental reliance to a favorable outcome. For example, in the stockbroker case, Dean Witter Reynolds, Inc. v. Continental Casualty Co., the court first focused on whether Continental Casualty, the investor, made a promise to purchase the bonds. ${ }^{101}$ The court pointed out that, although the testimony was conflicting, " $[t]$ he evidence produced by [Dean Witter] was sufficient to enable a jury to conclude that [Continental Casualty] made a clear and unambiguous promise to purchase the bonds." ${ }^{02}$ Notwithstanding the court's attention to whether there was a promise, the court also underscored the essentiality of Dean Witter's reliance. The court affirmed the jury's conclusion that Dean Witter reasonably relied on Continental Casualty's promise, stating: "[Dean Witter] suffered a $\$ 7$ million out-ofpocket-loss. Moreover, in reliance on [Continental Casualty's] promise, [Dean Witter] spent $\$ 7$ million to acquire the bonds . . ."103 It seems clear that the court would have declined to enforce Continental Casualty's promise if Dean Witter had not purchased the bonds.

In 2 of the 27 cases, courts found detrimental reliance that appears less definitive. In Wright $v$. Newman, for example, Newman gave birth to a son. ${ }^{104}$ Wright listed himself as the father on the birth certificate and gave the child his last name. ${ }^{105}$ The Georgia Supreme Court affirmed the trial court's finding that this amounted to a promise to support the child that was enforceable on promissory estoppel grounds. ${ }^{106}$ The court also found that Newman and her son detrimentally relied on the promise by foregoing the opportunity to identify and gain emotional and financial support from the child's natural father. ${ }^{107}$ A concurring judge pointed out the difficulty of determining and finding the natural father by the

97. See supra Table 4.1. 1994).

98. See Branco Enters., Inc. v. Delta Roofing, Inc., 886 S.W.2d 157, 158 (Mo. Ct. App.

99. See Pilot Oil Corp. v. Ohio Dep't of Transp., 656 N.E.2d 1379, 1380 (Ohio Ct. App. 1995).

100. See Dean Witter Reynolds, Inc. v. Continental Cas. Co., 897 F. Supp. 142, 143

(S.D.N.Y. 1995), aff'd, 101 F.3d 683 (2d Cir. 1996).

101. See id.

102. Id. at 142.

103. Id. at 143.

104. 467 S.E.2d 533, 534 (Ga. 1996).

105. See id.

106. See id. at 535 .

107. See id. 
time of the trial, some ten years after the child's birth. ${ }^{108}$ The dissent, however, questioned the reliance because of Wright's allegation that Newman broke off the relationship with Wright when the child was three, presumably at a time when Newman and her son could more easily have determined the true father's identity and gained support. ${ }^{109}$ The majority and concurrence either did not accept this rendition of the facts or believed them to be irrelevant. If the latter, perhaps the court is more concerned with the injustice of refusing to enforce Wright's "promise" of support than with detrimental reliance. But with the facts unclear, the case, on its own, hardly stands for the proposition that reliance generally does not matter.

In another case, the court found for a terminated employee at will who had forborn to follow up on a job application elsewhere and other possible openings because of assurances "that she did not need to look for another job."110 Because the employee may not have obtained another job, the reliance is somewhat ephemeral. On the other hand, the employee gave up the chance of receiving an offer elsewhere. This is a detriment that can be measured by the potential salary discounted by the chance that she would not have received a new job offer.

2. Reliance not discussed as a reason for success. - Courts in two cases successful on the merits did not discuss reliance. In one, the issue on appeal was whether the Labor Management Relations Act preempted the promissory estoppel claim. ${ }^{111}$ In the other, the issue on appeal was whether a conditional promise made by a general contractor to employ a subcontractor if the former was awarded a new building contract could be actionable under promissory estoppel. ${ }^{112}$ The various elements of promissory estoppel were not an issue on appeal in either case, so it is hardly surprising that neither court discussed reliance.

\section{B. Cases in Which the Party Making a Promissory Estoppel Claim Survived an Opposing Motion}

Overall, the 57 cases in which a promissory estoppel claim survived an opposing motion ${ }^{113}$ also stand for the proposition that courts require reliance. Nevertheless, it is fair to say that courts are more generous in finding all of the elements of promissory estoppel when the party asserting the claim is fighting off a motion. This should not be surprising be-

108. See id. at 536.

109. See id. at 537.

110. Howard v. Kuehnert, No. 95APE09-1197, 1996 WL 145517, at *3 (Ohio Ct. App. Mar. 28, 1996), appeal denied, 670 N.E.2d 243 (Ohio 1996).

111. See Lyons v. Teamsters Local Union No. 961, 903 P.2d 1214, 1219-20 (Colo. Ct. App. 1995) (holding promissory estoppel claim not preempted by the Labor Management Relations Act).

112. See Kemira, Inc. v. Williams Investigative \& Sec. Serv., Inc., 450 S.E.2d 427, 430-31 (Ga. Ct. App. 1994) (holding promise to perform an act conditional on a future event did not preclude the application of promissory estoppel).

113. See supra Table 4.1. 
cause the party asserting promissory estoppel must simply state a prima facie case. ${ }^{114}$ Courts thus may be skeptical of the promissory estoppel claim, but allow it to go forward to trial.

1. Reliance discussed. - In the 32 cases in this category, ${ }^{115}$ courts typically set forth the elements of the theory, often referring to the Restatement (Second) section 90, and then found factual issues that defeated the motion with respect to both promise and reliance. ${ }^{116}$ Some courts go out of their way to stress the importance of reliance. In Neiss $v$. Ehlers, for example, Neiss and Ehlers made an agreement to agree that Neiss would serve as the town of Ashland's dispensing optician and would receive "a one-third interest in Ashland's Optical Expressions as soon as it can be practically arranged." 17 After attempts to reach an agreement failed, Neiss brought a promissory estoppel claim against Ehlers. ${ }^{118}$ In defeating a motion for summary judgment by Ehlers and deciding that promissory estoppel could apply in the context of agreements to agree, the court stated:

The evil to be rectified through promissory estoppel is not the breach of the promise, but the harm that results from the promisor's inducement and the promisee's actions in reliance. The fact that a promise is indefinite, incomplete or even incapable of enforcement according to its own terms, does not mean that no redress should be possible for the damage that directly flows from the promisee's reliance on the promise. ${ }^{119}$

Not only did the court speak the language of reliance rather convincingly, but there was clear reliance in the case. Neiss was an optician living in Portland who gave up his job, moved to Ashland, and worked for Ehlers for two years in reliance on the agreement to agree. ${ }^{120}$

The strongest case for the proposition that courts focus on serious promises at the expense of the reliance requirement is Leblanc $v$. United Parcel Service, Inc. ${ }^{121}$ Leblanc, an employee at will at United Parcel Service

114. See Fed. R. Civ. P. 56(c).

115. See supra Table 4.1.

116. See, e.g., R.J. Longo Constr. Co. v. Transit Am., Inc., 921 F. Supp. 1295, 1305-06

(D.N.J. 1996); Neiss v. Ehlers, 899 P.2d 700, 703-04, 707-08 (Or. Ct. App. 1995).

117. 899 P.2d at 702.

118. See id. at 703.

119. Id. at 707.

120. See id. at 702; see also Lo Bosco v. Kure Eng'g Ltd., 891 F. Supp. 1020, 1031 (D.N.J. 1995) (plaintiff's resignation from law firm in reliance on defendant's promise of a joint venture "support[ed] a cause of action for promissory estoppel"); Hall v. Cropmate, 887 F. Supp. 1193, 1198-99 (S.D. Ind. 1995) ("[Employee] must still satisfy all of the elements of a claim for promissory estoppel .... To establish detriment, [he] 'must show that, had it not been for the promise, he would have obtained comparable medical insurance." (quoting Miller v. Taylor Insulation Co., 39 F.3d 755, 759 (7th Cir. 1994))); Patrick v. Painesville Comm. Props., Inc., 650 N.E.2d 927, 930 (Ohio Ct. App. 1994) (“[A] demonstration of detrimental reliance on specific promises of job security can create another exception to the doctrine of employment at will.").

121. No. 2:95-CV-68, 1996 WL 192011 (D. Vt. Apr. 2, 1996). 
for seventeen years, claimed that management assured him of continued employment. ${ }^{122}$ A written company policy allowed an employee to acknowledge the use of alcohol without losing his job. ${ }^{123}$ Leblanc did not allege in his complaint the reasons for his termination, but he referred to the alcohol policy. ${ }^{124}$ After setting forth promissory estoppel's reliance element, the court pointed out that the complaint did not allege a promise or reliance upon assurances of continued employment. ${ }^{125}$ Nonetheless, the court refused to dismiss the complaint, stating:

Although the pleadings are deficient in explicitly identifying the contents of the written policy, a reasonable interpretation of Leblanc's submissions suggests that he admitted to the use of alcohol in reliance upon a company representation that assured him of no reprisals, and that he was terminated based upon that admission. ${ }^{126}$

Although the court seemed to be charitable to Leblanc on the reliance (and promise) elements at the particular stage of the case, Leblanc clearly would have to show detrimental reliance if the case came to trial.

2. Reliance not discussed. - The 25 cases in which the promissory estoppel claimant defeated a motion but the court did not discuss reliance do not stand for the proposition that reliance is unnecessary. First, some of the cases involved issues on appeal that had nothing to do with the elements of promissory estoppel. ${ }^{127}$ For example, in CSO Servicing Corp. v. City of Eau Claire, the Wisconsin Court of Appeals reversed a summary judgment in favor of the defendant city, holding that a property-owner claimant's failure to seek certain statutory remedies did not preclude its claim of promissory estoppel based on the city's promise to purchase certain land.128 Second, other cases involved uncontested reliance claims. ${ }^{129}$ Third, in some cases, the court simply assumed, without discussion, the existence of reliance. ${ }^{130}$ No case that discussed the elements of promissory estoppel omitted reliance or found for the promissory estoppel claimant although there was no reliance.

122. See id. at $* 1$.

123. See id.

124. See id.

125. See id. at $* 5$.

126. See id.

127. See Brace v. City of Lakewood, 899 P.2d 301, 303 (Colo. Ct. App. 1995), rev'd, 919 P.2d 231 (Colo. 1996); CSO Servicing Corp. v. City of Eau Claire, 536 N.W.2d 731, 732 (Wis. Ct. App. 1995).

128. 536 N.W.2d at 733.

129. See, e.g., Decker v. Andersen Consulting, 860 F. Supp. 1300, 1309 (N.D. Ill. 1994) ("only element in dispute is whether [the promisor's] statements . . . constitute an unambiguous promise").

130. See, e.g., Shelley v. Trafalgar House Pub. Ltd., 918 F. Supp. 515, 522-23 (D.P.R. 1996) (issue of fact existed as to whether plaintiff relied on defendant's promise to negotiate in good faith). 
C. Cases in Which the Promissory Estoppel Claim Failed

In most of the 270 cases in which a promissory estoppel claim failed on the merits, ${ }^{131}$ the court found a defect in the promise, a defect in reliance, or a failure to satisfy the statute of frauds. Obviously, adverse decisions based only on a defect in the promise do not suggest that reliance is not required. Because each element of promissory estoppel is a prerequisite to recovery, courts that defeated a claim based on a defect in the promise simply did not have to proceed with their analyses to the reliance issue.

1. Defect in reliance discussed as a reason. - Particularly relevant to the issue of the importance of reliance are promissory estoppel cases that denied the claim primarily or exclusively because of a defect in reliance. ${ }^{132}$ Such cases include Norland $v$. Mahlum, where the buyer of the stock of a bank broke its promise to the bank's employees that they would keep their jobs after the transfer. ${ }^{133}$ The court declined to apply promissory estoppel in favor of the employee son of the seller, however, because the son did not rely to his detriment. ${ }^{134} \mathrm{He}$ continued working until the transfer to the buyer and did not turn down other employment offers after the promise of continued employment. 135

In McKenny v. John V. Carr $\mathcal{E}^{2}$ Son, Inc., McKenny sold his stock in his business to Carr and became Carr's employee. ${ }^{136}$ McKenny brought a claim of promissory estoppel based on Carr's alleged oral promises of termination only for cause and of the lack of need for a written contract. ${ }^{137}$ The court found the first promise of just-cause employment too indefinite, but the second specific enough so that McKenny had "met the first element of promissory estoppel."138 The court also found that McKenny reasonably believed Carr's promise that no written contract was necessary because of friendship and trust between the parties. ${ }^{139}$ However, the court failed to recognize McKenny's claim of forbearance to demand a written contract as a change in position because of the absence of evidence that Carr would have agreed to a written contract or that McKenny would have declined to sell his stock if Carr had not provided one. ${ }^{140}$ In addition, McKenny had offered no evidence that he was induced to sell his stock based on a promise of "just cause employment."

131. See supra Tables 1.1 and 1.2.

132. See supra Table 5.2.

133. No. C2-94-561, 1994 WL 510142, at *1 (Minn. Ct. App. Sept. 20, 1994).

134. See id. at *2.

135. See id.

136. 922 F. Supp. 967, 971 (D. Vt. 1996).

137. See id. at 980 .

138. Id.

139. See id.

140. See id.

141. See id. 
Some cases focusing on reliance could have been decided on the basis of a defect in the promise. In Pavel Enterprises, Inc. v. A.S. Johnson Co., for example, Pavel made a bid to be the general contractor on a construction project for the National Institutes of Health (NIH) ${ }^{142}$ Pavel solicited bids from subcontractors and Johnson gave a verbal bid, which Pavel used in its own bid. ${ }^{143}$ Initially, Pavel did not receive the general contract but, a few weeks later, after the low bidder was disqualified, NIH notified Pavel that it would accept Pavel's bid. ${ }^{144}$ Pavel then talked with Johnson about its proposed role and also asked for all subcontractors to resubmit bids. ${ }^{145}$ A few days later, Pavel informed Johnson that Pavel was accepting Johnson's original verbal bid. ${ }^{146}$ Johnson then withdrew its bid because of an error, but Pavel refused to release Johnson. ${ }^{147}$ The Maryland Court of Appeals affirmed the trial court's determination that Johnson's bid constituted an offer that was actionable on promissory estoppel grounds. ${ }^{148}$ Nevertheless, the court held that Johnson could not reasonably have expected Pavel to rely on Johnson's bid because of the time lapse between the opening of Pavel's bid and the award of the contract to it. ${ }^{149}$ Moreover, Pavel did not actually rely on Johnson's bid because it asked all subcontractors to resubmit bids. ${ }^{150}$

The court in Pavel could have decided the case based on a defect in the promise. It could have concluded that, because of the time duration between Johnson's offer and Pavel's award of the NIH contract, a reasonable person in Pavel's position would have believed that Johnson's promise to do the work had lapsed. Nevertheless, this does not mean that the lack of reliance in the case was unimportant or that a defect in the promise was the only real reason for the court's holding. Rather, it shows the close relationship of promise and reliance, namely that the promise must induce a reasonable change in position on the promisee's part. Pavel illustrates that a party cannot show reasonable reliance where the promise has lapsed.

These decisions call into question the promise theorists' arguments that "serious" promises or those made "in furtherance of an economic activity" are enforced in the absence of reliance. ${ }^{151}$ Perhaps the court in

142. 674 A.2d 521, 523 (Md. 1996).

143. See id.

144. See id.

145. See id. at 523-24.

146. See id. at 524.

147. See id. at 525 .

148. See id. at 533 .

149. See id.

150. See id.

151. See also Bellini v. University of St. Thomas, No. C6-94-367, 1994 WL 425166, at *5 (Minn. Ct. App. Aug. 16, 1994) (no reliance on a document that appellant could not remember having seen); Coleman v. CMI Transp., 635 N.Y.S.2d 212, 213 (App. Div. 1995) ("Assuming that plaintiff was promised an equity interest in defendant corporation in exchange for his services on its behalf, he suffered no unconscionable injury as evidenced by the substantial weekly compensation he received."); Lahr Constr. Corp. v. J. Kozel \& 
Pavel captured the promissory estoppel environment best when it stated: "We prefer to use the phrase detrimental reliance, rather than the traditional nomenclature of 'promissory estoppel,' because we believe it more clearly expresses the concept intended." 152

2. Defect in Reliance not discussed as a reason. - In general, courts did not discuss a defect in reliance as a reason for their decisions when they had already concluded that the promissory estoppel claim would necessarily fail on some other ground. Common grounds for denying a claim before reaching the issue of reliance included the absence of a definite and clear promise, ${ }^{153}$ the presence of a governing contract, ${ }^{154}$ and failure to satisfy the statute of frauds or another statute. ${ }^{155}$ Some courts went out of their way to mention that even if there were a definite promise the claim would fail because of the absence of reasonable reliance. ${ }^{156}$

\section{Cases on Remedies}

Despite illustrating an assortment of remedial outcomes and some remedial confusion, the 1994-1996 cases nevertheless suggest that the remedial approach of courts is not always expectancy damages. Because expectancy damages-putting the injured party in as good a position as if the promise was performed-can be viewed as a surrogate for enforcing the promise, ${ }^{157}$ the failure of courts to turn uniformly to this remedy further dilutes the argument made by the promise studies that the courts focus exclusively on promise.

Not only do 7 of 14 cases clearly awarding damages appear to grant reliance damages, ${ }^{158}$ but those cases are full of language suggesting the widespread acceptance of reliance damages as a remedy. For example, "'[p]revailing on a promissory estoppel claim ... sometimes entitles a party only to its out-of-pocket expenses, rather than to benefit-of-the bar-

Son, Inc., 640 N.Y.S.2d 957, 961 (Sup. Ct. 1996) (finding that despite "undisputed evidence of a clear and unambiguous promise or bid," promisee did not rely).

152. Pavel, 674 A.2d at 523 n.1.

153. See, e.g., Kiely v. Raytheon Co., 914 F. Supp. 708, 712 (D. Mass. 1996), aff'd, 105 F.3d 734 (1st Cir. 1997); Orback v. Hewlett-Packard Co., 909 F. Supp. 804, 809-10 (D. Colo. 1995), aff'd, 97 F.3d 429 (10th Cir. 1996), cert. denied, 117 S.Ct. 1846 (1997); Silcott v. Rio Linda Chem. Co., No. 95APE11-1512, 1996 WL 303679, at *3 (Ohio Ct. App. June 4, 1996).

154. See, e.g., Piantes v. Pepperidge Farm, Inc., 875 F. Supp. 929, 935 (D. Mass. 1995).

155. See, e.g., Broward County v. Conner, 660 So. 2d 288, 290 (Fla. Dist. Ct. App. 1995); Harkinson v. Trammell Crow Co., 915 S.W.2d 28, 37 (Tex. App. 1995) aff'd in part and rev'd in part, 944 S.W.2d 631 (Tex. 1997).

156. See, e.g., Johnson v. Cadillac Plastics Group, Inc., 908 F. Supp. 847, 852 (D. Colo. 1995) ("[A] policy statement too vague to constitute an offer of employment . . . is also too vague to create on the part of an employer a reasonable expectation of reliance."); Piantes, 875 F. Supp. at 935 (even if there were a promise, enforcement "not necessary to prevent injustice").

157. See infra notes 201-202 and accompanying text.

158. See supra Table 7.1. 
gain damages." 159 And more: "The doctrine of promissory estoppel may be available to an at-will employee, but the remedy is limited to damages actually resulting from the detrimental reliance . ..."160

Despite such language, the 1994-1996 cases that deal with remedies are inconclusive for the reasons set forth previously. ${ }^{161}$ For example, in Percy J. Matherne Contractor, Inc. v. Grinnell Fire Protection Systems Co., ${ }^{162}$ the measure of reliance and expectancy damages coincide, thereby diluting the significance of the award of one or the other. Matherne relied on Grinnell's bid in making an irrevocable bid on a construction project. After Grinnell repudiated its bid, the court awarded Matherne "the expenses incurred as a direct result of its reliance" and found these to be "the difference between the Grinnell bid and the replacement contract."163 Matherne would have been entitled to the same measure of damages based on lost expectancy. ${ }^{164}$ The reliance and expectancy measures are identical in some of the cases seemingly awarding expectancy damages as well. ${ }^{165}$

One conclusion is possible from the data. The number of cases apparently awarding either an expectancy recovery or reliance damages shows that courts take seriously the admonition of the second Restatement to award damages as justice requires.

\section{A Second Look at Some of the Cases in the Promise Studies}

Part II speculated on possible explanations for the dramatic lack of success of promissory estoppel in the courts during 1994-1996. It suggested that the data may reveal a judicial souring on promissory estoppel, which may not have been generally perceived by litigants during those years. ${ }^{166}$ Similarly, one could explain the importance of reliance that is revealed by the data as a new development. This explanation would be consistent with the promise studies' earlier finding of the diminished role of reliance. However, although the authors of the promise studies have done an excellent job of mounting an argument in favor of the dominance of promise in the cases they studied, there is ample room to inter-

159. Cyberchron Corp. v. Calldata Sys. Dev., Inc., 47 F.3d 39, 46 (2d Cir. 1995) (quoting Arcadian Phosphates, Inc. v. Arcadian Corp., 884 F.2d 69, 73 (2d Cir. 1989)). 1994).

160. Jarboe v. Landmark Community Newspapers, Inc., 644 N.E.2d 118, 122 (Ind.

161. See supra Part II.C.

162. 915 F. Supp. 818 (M.D. La. 1995).

163. Id. at 826.

164. See also Branco Enters. v. Delta Roofing, Inc., 886 S.W.2d 157, 161 (Mo. Ct. App. 1994).

165. See, e.g., Royal Fixture Co. v. Phoenix Leasing, Inc., 891 S.W.2d 553, 556 (Mo. Ct. App. 1995); Villagran v. Central Ohio Bus. Serv., Inc., No. 94APE08-1267, 1995 WL 347419 , at $* 9$ (Ohio Ct. App. June 8, 1995).

166. See supra notes $77-79$ and accompanying text. 
pret those cases as also supporting, or at least not contradicting, the crucial role of reliance. ${ }^{167}$

Section A discusses those cases that the promise studies suggest illustrate the unimportance of reliance. Despite some strong anti-reliance rhetoric, ${ }^{168}$ the authors of the promise studies do not argue that courts fail to speak the language of reliance or even that the claimant failed to rely in successful promissory estoppel cases. Instead, they seek to explain away the courts' references to reliance or the actual reliance. For example, one of Yorio and Thel's explanations for courts' discussion of reliance is that reliance serves cautionary and evidentiary roles. ${ }^{169}$ Even if these were the only functions of reliance, however, they are hardly secondary roles. After all, Lon Fuller set forth these reasons as two of the primary formal justifications for the requirement of consideration in bargain cases. ${ }^{170}$ But the cases discussed in the promise studies also stand for the proposition that the justice of compensating a party for induced detrimental reliance is an important factor in the decisions.

The promise theorists also posit that courts generally do not require detrimental reliance or that the promise induced reliance. ${ }^{171}$ However, such assertions lead to an inconclusive discussion of whether the reliance, measured objectively, actually hurt the promisee, or a debate about whether the promisee would have proceeded in the same fashion without the promise. It is quite possible that the reliance did hurt and was induced by the promise even in the cases that are supposed to demonstrate the unimportance of reliance.

Section B discusses the remedy employed in these cases. Despite multiple explanations for why courts most often chose expectancy damages, the authors of the promise studies settle unconvincingly on the conclusion that expectancy recoveries show that reliance did not really matter.

167. This section is adapted from Hillman, supra note 2 , at $63-74$, with permission of Kluwer Academic Publishers (homepage: http://www.wkap.nl).

168. "[R]eliance is no longer the key to promissory estoppel." Farber \& Matheson, supra note 7, at 904. "Issues of both liability and remedy under Section 90 turn on promise, not reliance." Yorio \& Thel, supra note 5, at 167. "[T] he reported cases cannot be explained on the basis of reliance." Id. at 161.

169. "[Reliance] makes it more likely that the promisor should have expected the promise to induce that action. Substantial action by the promisee also serves an evidentiary function by increasing the likelihood that a promise was in fact made." Yorio \& Thel, supra note 5, at 159 .

170. See Lon Fuller, Consideration and Form, 41 Colum. L. Rev. 799, 800 (1941). Yorio and Thel also mention that courts' use of reliance "'gild[s] the lily' by emphasizing the harm suffered by the promisee in relying on the promise." Yorio \& Thel, supra note 5, at 159 . But why does this relegate reliance to a secondary position?

171. See Yorio \& Thel, supra note 5, at 152 (" $[C]$ ourts do not require actual inducement under Section 90 . Nor do they insist that the promisee suffer a detriment by relying on the promise."). 


\section{A. Cases Set Forth to Demonstrate the Diminished Role of Reliance As a} Substantive Basis for Enforcing Promises

Vastoler v. American Can Co. ${ }^{172}$ is one (of two) of the principal examples of the decline of reliance discussed in the text of Farber and Matheson's article. ${ }^{173}$ Vastoler, an employee, accepted a promotion to the position of supervisor, based on American Can's promise of pension benefits in the new position. ${ }^{174}$ Vastoler brought a claim of promissory estoppel after American Can broke its promise to extend the benefits, even though Vastoler enjoyed higher pay and other financial advantages in the new position. ${ }^{175}$ The trial court granted summary judgment to American Can on Vastoler's promissory estoppel claim based on the view that the advantages of Vastoler's new position outweighed the promised pension benefits. The Third Circuit reversed and remanded the case for trial because Vastoler may have forgone other opportunities and because "the human dynamics and anxieties" of being a supervisor may cause "stress and emotional trauma." 176

In my view, Vastoler is not a dramatic example of a court finding detrimental reliance when there really is none. First, despite Farber and Matheson's belief otherwise, ${ }^{177}$ the detriment of job stress and pressure in a supervisory position may have been real and significant. Granted, the case may show that the court was willing to consider a more expansive and subjective notion of detriment, including a promisee's mental suffering. Farber and Matheson criticize this result: "[I]f psychological factors are sufficient to support a claim of promissory estoppel, relatively few promises will fail to qualify for enforcement."178 Perhaps the authors are right that psychological factors should not count, even if real, because of a floodgates problem. ${ }^{179}$ But this does not mean that the court really believed there was no detrimental reliance or that in fact there was no detrimental reliance. If Farber and Matheson are right, it means only that, as a policy matter, the particular detrimental reliance should not count. ${ }^{180}$

Another reason not to put too much stock in Vastoler is that Vastoler apparently did not pursue a breach of contract claim because of a technical flaw in the theory, perhaps the lack of a writing. ${ }^{181}$ The court there-

172. 700 F.2d 916 (3d Cir. 1983).

173. See Farber \& Matheson, supra note 7, at 910-12.

174. See id. at 917.

175. See id.

176. Id. at 919.

177. See Farber \& Matheson, supra note 7, at 912.

178. Id.

179. But there would be ways of drawing lines. A promisee's testimony of his or her subjective beliefs and feelings would not be enough, for example.

180. Farber and Matheson's other principal example, Oates v. Teamster Affiliates Pension Plan, 482 F. Supp. 481 (D.D.C. 1979), also involves reliance that arguably should be measured subjectively. See Farber \& Matheson, supra note 7, at 912-14.

181. See Farber \& Matheson, supra note 7, at 911 n.31. 
fore may have been motivated to decide in favor of Vastoler because American Can's promise was part of a bargain. In fact, Farber and Matheson concede that many of the cases they offer to support their thesis of the diminished role of reliance involve imperfect bargains. ${ }^{182}$ Vastoler therefore does not suggest that reliance is unimportant in cases where there was no bargain.

Yorio and Thel rely in part on the venerable Devecmon v. Shaw ${ }^{183}$ to demonstrate the unimportance of reliance..$^{184}$ In Devecmon, an uncle promised to pay for his nephew's trip to Europe and the nephew took the trip. ${ }^{185}$ The court enforced the uncle's promise based on the bargain theory. ${ }^{186}$ Yorio and Thel analyze the case on the grounds of promissory estoppel, however, because they believe the nephew's trip did not constitute consideration. ${ }^{187}$ They point out that the court apparently did not require proof that the nephew's trip was induced by his uncle's promise. ${ }^{188}$ But such inducement is entirely plausible; in fact, the court believed the nephew probably was induced: "It might very well be, and probably was the case, that the plaintiff would not have taken a trip to Europe at his own expense." 189 After all, for most young people, even today, a similar promise from a benefactor would be a precondition for a trip to Europe..$^{190}$

Yorio and Thel also discuss cases in which courts have enforced a promise to pay insurance premiums for an insured who appears unable to pay, after the promisor breaks the promise, the insurance coverage expires, and a loss otherwise under the policy occurs. ${ }^{191}$ The authors as-

182. See id. at $913-14$ n.43.

183. 14 A. 464 (Md. 1888).

184. See Yorio \& Thel, supra note 5 , at 155 .

185. See Devecmon, 14 A. at 464.

186. See id. at 464-65.

187. See Yorio \& Thel, supra note 5 , at 155.

188. See id.

189. Devecmon, $14 \mathrm{~A}$. at 464 .

190. Huhtala v. Travelers Ins. Co., 257 N.W.2d 640 (Mich. 1977), is supposed to "demonstrate even more clearly" that a detriment is not required. Yorio \& Thel, supra note 5 , at $155 \&$ n.307. Huhtala failed to file a claim for injuries from an auto accident against Travelers' insured in time because the company promised to settle the claim fairly. The extent of injuries was not clear at the time of the promise. Yorio and Thel rely on language in the case focusing on the promise, but the court's statement was in the context of determining whether promissory estoppel was governed by the six-year contracts statute of limitations or the three-year torts statute of limitations:

We do not wish to be understood as indicating any view on the merits of plaintiffs' claim. We hold only that Count I of the complaint states a claim of promissory estoppel, albeit somewhat inartfully, and that the 6-year statute of limitations governs the time for commencing an action stating such a claim.

Huhtala, 257 N.W.2d at 647-48. Travelers therefore could still establish that it had not made a promise or that Huhtala did not reasonably rely on the promise.

191. See Yorio \& Thel, supra note 5, at 155-56 \& n.308 (discussing Spiegel v. Metropolitan Life Ins. Co., 160 N.E.2d 40 (N.Y. 1959) and East Providence Credit Union v. Geremia, 239 A.2d 725 (R.I. 1968)). 
sert that the promisee could not have relied on the promise because the promisee could not pay. ${ }^{192}$ However, most of the cases do not focus on why the promisee could not pay or whether the promisee could have borrowed or raised money if necessary. ${ }^{193}$ A fair hypothesis may be that the insured would have pursued those possibilities but for the promise.

Yorio and Thel also believe "there is nothing special about reliance"194 based on the favored position of charitable institutions that receive pledges. The second Restatement section 90(2) specifically exempts these organizations from the requirement of proving reliance ${ }^{195}$ because of their importance. ${ }^{196}$ Yorio and Thel suggest that this section helps prove the relative unimportance of reliance in other contexts. ${ }^{197}$ This seems like peculiar treatment for an exception to a rule, which is created because of differences in context from the main body of cases. When the special-treatment-for-charities rationale is inapposite, the implication should be that reliance is required. 198

Yorio and Thel also reason that: "[R]eliance theory does not explain why in Section 90 cases courts insist that there be a promise. If the basis of recovery were harm caused by the defendant's conduct, it should not matter whether the conduct constituted a promise." 199 However, section 90 focuses on promise-induced reliance because theories such as equitable estoppel and misrepresentation already protect parties from reasonable detrimental reliance induced by conduct and statements. By fashioning liability for promise-induced reliance, promissory estoppel simply fills a gap in the other doctrines.

Finally, Yorio and Thel find significance in the fact that courts deny recovery under promissory estoppel when the promisor cannot foresee the damages: "If reliance were the basis of Section 90 , harm suffered by the promisee would mandate a remedy and foreseeability by the promisor would not matter." 200 Theories of liability need not be absolute, how-

192. See Yorio \& Thel, supra note 5 , at 156.

193. See, e.g., Spiegel, 160 N.E.2d at 40; East Providence Credit Union, 239 A.2d at 725. 194. Yorio \& Thel, supra note 5 , at 161.

195. Comment (f) provides that the "probability of reliance" is sufficient. Restatement (Second) of Contracts $\$ 90 \mathrm{cmt}$. $\mathrm{f}$ (1981).

196. See Yorio \& Thel, supra note 5, at 153.

197. See id. ("Charitable subscriptions ... pose a significant threat to the view that the objective of Section 90 is to protect a promisee who has suffered loss in reliance on the promise.").

198. See Eisenberg, supra note 5, at 861 . Some courts previously required reliance on promises to charities. See Benjamin F. Boyer, Promissory Estoppel: Requirements and Limitations of the Doctrine, 98 U. Pa. L. Rev. 459, 471 (1950) ("[T]he charity . . should show that the subscription induced it to change position. If no such change was caused, enforcement is properly denied.").

199. Yorio \& Thel, supra note 5, at 161-62 (footnote omitted). Courts in 1994-1996 did not always require a clear promise. See, e.g., Neiss v. Ehlers, 899 P.2d 700, 707 (Or. Ct. App. 1995).

200. Yorio \& Thel, supra note 5 , at 160 . 
ever. The requirement of foreseeability seems a reasonable manner of determining when detrimental reliance should be compensated.

\section{B. Cases Involving the Remedy for Promissory Estoppel}

As already noted, the authors of the promise studies report that courts award expectancy rather than reliance damages in promissory estoppel cases, unless the former are unavailable for a technical reason. ${ }^{201}$ If so, this would be some evidence of courts' preoccupation with promise at the expense of reliance because the court's remedy would substitute for performance of the promise and not simply remedy the harm done by reliance. But Farber and Matheson recognized that the evidence of expectancy damages may be misleading because of other explanations for the use of the expectancy formula. ${ }^{202}$ Undeterred, Yorio and Thel spend a considerable amount of time attempting to refute some of these explanations.

One explanation for the frequent award of expectancy damages is that they may be easier to prove than reliance damages. Yorio and Thel concede that " $[t]$ his explanation works reasonably well when reliance damages are difficult or impossible to calculate."203 But instead of determining how often courts opt for expectancy damages for this reason, ${ }^{204}$ they seek to show that courts choose expectancy damages even when reliance damages are not difficult to measure. For example, in Ricketts $v$. Scothorn, a granddaughter quit her $\$ 10$ per week bookkeeper position after her grandfather gave her a $\$ 2000$ promissory note and told her she could quit her job. ${ }^{205}$ Nevertheless, she returned to work as a bookkeeper for another firm about a year later. ${ }^{206}$ The court enforced the note after the grandfather died and his administrator refused to pay it.207 Yorio and Thel assert that the court had "a clear choice" between award-

201. See Farber \& Matheson, supra note 7, at 909 (“ $[R]$ ecent cases are heavily weighted towards the award of full expectation damages."); see also Becker, supra note 52, at 135 ("[C]ourts routinely award expectation damages unless those damages are too speculative, indefinite, or otherwise unavailable. ... ).

202. See Farber \& Matheson, supra note 7, at 909 n.24 ("Depending on how the expectation and reliance interests are conceptualized, the two measures may tend to produce the same results.").

203. Yorio \& Thel, supra note 5, at 134.

204. This may be quite common. Yorio and Thel rely heavily on Tomerlin $v$. Canadian Indemnity Co., 394 P.2d 571 (Cal. 1964), a case in which the court discussed the choice of remedies and ultimately selected expectancy damages. They note that "[t]his passage from a California opinion evidences what Williston discovered and reported in the 1920's: the remedy routinely granted in Section 90 cases is enforcement of the promise either by expectation damages or by specific performance." Yorio \& Thel, supra note 5, at 129. The Tomerlin court's choice, however, was based on the fact that reliance damages "would impose upon plaintiff the impossible burden of proving, on remand, the precise extent of the loss." Tomerlin, 394 P.2d at 578.

205. 77 N.W. 365, 366 (Neb. 1898).

206. See id.

207. See id. at 367. 
ing the granddaughter her lost income of roughly $\$ 520$ before she began her new job or her expectancy based on the promise of $\$ 2000$ plus interest. ${ }^{208}$ The court's opinion does not mention how much she earned at her new job, however, or whether it was inferior to the original one. If the new job was inferior or the pay was lower, the granddaughter's reliance damages may have been much greater than $\$ 520$. In short, despite Yorio and Thel's assertions, reliance damages may have been difficult to measure, thereby leading to the expectancy award.

Yorio and Thel also maintain that promissory estoppel courts "face a clear choice" between granting expectancy in the form of a specific performance decree and reliance damages "in cases involving improvements [ ] to land."209 They state that "[c]ourts routinely grant specific performance." 210 However, these cases frequently involve exchanges of land for services or the like that are unenforceable on some technical ground. ${ }^{211}$ Courts comfortable with granting specific performance in such "bargain" settings may reflexively choose it, which says little about the appropriate remedy in promissory estoppel cases where there is no bargain. More important, reliance damages may be difficult to evaluate, for example, because of the length of time between the promise and the lawsuit.212 Consider the difficulty of proving the cost of improvements to land made by a promisee over a long period of time. ${ }^{213}$ In addition, the passage of time may obscure the cost of lifestyle changes induced by the promise of land, such as changes in living and working arrangements. ${ }^{214}$

Another explanation for the predominance of expectancy awards in Farber and Matheson's sample is that the courts compensate promisees for their forgone opportunities, which in a market economy often may be equivalent to lost expectancy. ${ }^{215}$ Courts have explicitly recognized this theory. In Walters v. Marathon Oil Co., for example, Marathon Oil broke a promise to provide a dealership to the Walters and the court stated: "[I]t is apparent that [the Walters] suffered a loss of profits as a direct result of their reliance upon the promise made by [Marathon]."216 Yorio and Thel nevertheless dismiss the forgone opportunities explanation, asserting that courts routinely award expectancy damages even in donative promise cases where the promisee typically has not forgone other oppor-

208. See Yorio \& Thel, supra note 5, at 134.

209. Id. at 135.

210. Id. All but one cited case, however, were decided prior to 1932, when the first Restatement formalized promissory estoppel. See id. at 135 n.149.

211. See, e.g., Wadsworth v. Hannah, 431 So. 2d 1186, 1189 (Ala. 1983); see also Becker, supra note 52 , at $140-41$.

212. See Becker, supra note 52, at $139-40$.

213. See id.

214. See Boyer, supra note 198, at 486; see also Eisenberg, supra note 29, at 28 (discussing the difficulty of quantifying "nonfinancial" costs such as moving).

215. See Becker, supra note 52, at 139, 143-44; Eisenberg, supra note 29, at 26-28.

216. 642 F.2d 1098, 1100 (7th Cir. 1981). 
tunities. ${ }^{217}$ But one would have hoped for more direct evidence before dismissing the forgone opportunities explanation in commercial cases.

In light of their assertion that courts "invariably" award expectancy damages if measurable, Yorio and Thel also attempt to diminish the importance of decisions that appear to award reliance damages. 218 In Goodman v. Dicker, for example, the circuit court reversed the district court's grant of expectancy damages and awarded reliance damages. ${ }^{219}$ Yorio and Thel argue that the case is inapposite because the defendants, distributors of Emerson Radio products, misrepresented to the plaintiffs that they would be granted a dealership. They reason that the defendants were not agents of Emerson and had no authority to bind it. Therefore the plaintiffs could not have reasonably believed that the defendants could promise a dealership. ${ }^{220}$ Yorio and Thel concede, however, that the Goodman court characterizes the defendants' representations as a promise. ${ }^{221}$ Moreover, the relationship of the distributors and dealer and what the plaintiffs knew about the relationship is unclear. The plaintiffs may have reasonably believed that the distributors had authority to bind Emerson and had promised a dealership.

Yorio and Thel also discuss Wheeler $v$. White, where the court granted Wheeler reliance damages after he demolished his buildings in reliance on White's promise to procure or grant Wheeler a loan to build a new commercial building. ${ }^{222}$ White's promise was part of an unenforceable agreement because the parties failed to specify the interest rate and related matters. ${ }^{223}$ The court denied Wheeler lost profits "even if ... provable with certainty."224 Notwithstanding the court's explicit language, Yorio and Thel assert that the decision is "ambiguous" as to the remedy. ${ }^{225}$ They speculate that if Wheeler had secured an alternative loan the court probably "would have granted expectation damages under the promissory estoppel count" measured by the difference in interest rates. ${ }^{226}$ But the court could have proceeded in this fashion only if Wheeler and White had agreed on an interest rate. In that case, the court would have been able to enforce the contract rather than employ promissory estoppel and the award of expectancy damages would have been unexceptional. In addition, the difference-in-the-interest-rates

217. See Yorio \& Thel, supra note 5, at 133.

218. See id. at $139-51$.

219. 169 F.2d 684, 685 (D.C. Cir. 1948).

220. See Yorio \& Thel, supra note 5, at 140. Yorio and Thel contrast Chrysler Corp. v. Quimby, 144 A.2d 123 (Del. 1958), where the court found that Chrysler's own executives' misrepresentations that Quimby would get a controlling interest in a dealership constituted a promise. See Yorio \& Thel, supra note 5, at 141-42.

221. See Yorio \& Thel, supra note 5 , at 140.

222. 398 S.W.2d 93, 95, 97 (Tex. 1965).

223. See id. at 95 .

224. Id. at 97.

225. See Yorio \& Thel, supra note 5 , at 148 .

226. Id. 
formula posited by Yorio and Thel would have been an accurate way of measuring Wheeler's reliance (as well as expectancy) damages. Wheeler could have reasonably minimized his reliance damages by securing the substitute higher interest-rate loan and finishing the project. Based on the avoidable consequences rule, the recoverable reliance damages caused by White's broken promise therefore would have been the difference in the interest rates. ${ }^{227}$

\section{The Problem of Overgeneralization}

The promise theorists' assertion of the relative unimportance of reliance seems much less persuasive after reviewing the cases and arguments used to support it. The cases are not impressive in number and can be read in more than one way. ${ }^{228}$ Although Farber and Matheson read over two hundred cases, they discuss only a few that are supposed to show that courts generally stretch their analysis to find reliance in successful promissory estoppel cases. In fact, Farber and Matheson state their thesis much less ambitiously in their conclusion: "In key cases promises have been enforced with only the weakest showing of any detriment to the promisee."229 But the reader is left wondering why the cases discussed are "key." Further, Yorio and Thel's case sample is not large; they rely predominantly on the cases cited by the Restatements and by Farber and Matheson. ${ }^{230}$

An alternative reading of the sample cases suggests the importance of both promise and reliance. In fact, Farber and Matheson ultimately acknowledge the limitations of an all-or-nothing analysis of the substantive core of promissory estoppel: "[W]e are skeptical of claims that the common law can be reduced to a simple set of rules, as well as claims that the proper resolution of contracts issues can be deduced from some set of abstract principles." 231

\section{CONCLUSION}

Analysts of promissory estoppel have predicted that the theory would "swallow up" bargain theory. Even discounting such hyperbole, the amount of ink that has been spilled by scholars analyzing promissory es-

227. Yorio and Thel also attempt to distinguish other cases. See Yorio \& Thel, supra note 5, at $132 \mathrm{n} .130$ (distinguishing cases written by "former law school professors"); id. at 143 (distinguishing Hoffman v. Red Owl Stores, 133 N.W.2d 267, 277 (Wis. 1965), which held that an agent's statements that Hoffman would get a Red Owl store constituted a promise and entitled Hoffman to reliance damages).

228. Farber and Matheson make this point themselves: "[M]ost cases denying recovery, purportedly for lack of reasonable reliance, can be readily explained on other grounds." Farber \& Matheson, supra note 7, at 904. This, of course, only means that there may be more than one explanation for a decision, not that "reliance is no longer the key to promissory estoppel." Id.

229. Id. at 945 (emphasis added).

230. See, e.g., Yorio \& Thel, supra note 5, at 130-31, 139.

231. Farber \& Matheson, supra note 7, at 946. 
toppel certainly suggests the importance, if not dominance, of the theory. Measured in terms of win rates in the courts, however, promissory estoppel may no longer be, if it ever was, a significant theory of recovery.

Analysts have also reported the unimportance of reliance as a substantive element of promissory estoppel and the invariable award of expectancy damages in successful cases. The reality, at least during the mid1990s, was very different. A showing of reliance was crucial to recovery and the remedy was not exclusively expectancy damages.

Perhaps courts should enforce promises made in the pursuit of economic activity or, even more broadly, enforce all serious promises, without a showing of a bargain or reliance. Resolution of this issue requires discourse on the normative bases for enforcing promises and judgments about the merits of these reasons. I have looked at these questions elsewhere ${ }^{232}$ and I want to get back to them in the context of promissory estoppel, but the purpose of this Article is to show that courts do not enforce promises without a bargain or reliance.

Commentators sometimes seem too zealous to find the "key" element of one law or another and seem unwilling to admit how complex the law may be. In the area of promise enforcement, the 1994-1996 promissory estoppel cases reveal the importance of both promise and reliance, with courts emphasizing one or the other based on the particular facts of a case.

232. See Hillman, supra note 2. 